\title{
25CN-NBOMe Metabolites in Rat Urine, Human Liver Microsomes and C. elegans-Structure Determination and Synthesis of the Most Abundant Metabolites
}

\author{
Anna Šuláková ${ }^{1}$, Jitka Nykodemová ${ }^{2}$, Petr Palivec ${ }^{2}$, Radek Jurok ${ }^{3}$, Silvie Rimpelová ${ }^{4} \oplus$, Tereza Leonhardt ${ }^{4}$, \\ Klára Šíchová ${ }^{1}$ (D) Tomáš Páleníček ${ }^{1}$ and Martin Kuchař ${ }^{1,2, * \mathbb{D}}$ \\ 1 Department of Experimental Neurobiology, National Institute of Mental Health, Topolová 748, \\ 25067 Klecany, Czech Republic; anna.sulakova@nudz.cz (A.Š.); klara.sichova@nudz.cz (K.Š.); \\ tomas.palenicek@nudz.cz (T.P.) \\ 2 Forensic Laboratory of Biologically Active Substances, Department of Chemistry of Natural Compounds, \\ University of Chemistry and Technology Prague, Technická 5, 16628 Prague, Czech Republic; \\ nykodemj@vscht.cz (J.N.); palivecp@vscht.cz (P.P.) \\ 3 Department of Organic Chemistry, University of Chemistry and Technology Prague, Technická 5, \\ 16628 Prague, Czech Republic; jurokr@vscht.cz \\ 4 Department of Biochemistry and Microbiology, University of Chemistry and Technology Prague, Technická 5, \\ 16628 Prague, Czech Republic; rimpelos@vscht.cz (S.R.); pikalovt@vscht.cz (T.L.) \\ * Correspondence: kuchara@vscht.cz; Tel.: +420-220-444-431
}

Citation: Šuláková, A.;

Nykodemová, J.; Palivec, P.; Jurok, R.; Rimpelová, S.; Leonhardt, T.; Šíchová, K.; Páleníček, T.; Kuchař, M. 25CN-NBOMe Metabolites in Rat Urine, Human Liver Microsomes and C. elegans-Structure Determination and Synthesis of the Most Abundant Metabolites. Metabolites 2021, 11, 212. https://doi.org/10.3390/ metabo11040212

Academic Editor: Markus R. Meyer

Received: 28 February 2021

Accepted: 29 March 2021

Published: 31 March 2021

Publisher's Note: MDPI stays neutral with regard to jurisdictional claims in published maps and institutional affiliations.

Copyright: (C) 2021 by the authors Licensee MDPI, Basel, Switzerland. This article is an open access article distributed under the terms and conditions of the Creative Commons Attribution (CC BY) license (https:// creativecommons.org/licenses/by/ $4.0 /)$
Abstract: $N$-Benzylphenethylamines are novel psychedelic substances increasingly used for research, diagnostic, or recreational purposes. To date, only a few metabolism studies have been conducted for N-2-methoxybenzylated compounds (NBOMes). Thus, the available 2,5-dimethoxy-4-(2-((2methoxybenzyl)amino)ethyl)benzonitrile (25CN-NBOMe) metabolism data are limited. Herein, we investigated the metabolic profile of 25CN-NBOMe in vivo in rats and in vitro in Cunninghamella elegans (C. elegans) mycelium and human liver microsomes. Phase I and phase II metabolites were first detected in an untargeted screening, followed by liquid chromatography-tandem mass spectrometry (LC-MS/MS) identification of the most abundant metabolites by comparison with in-house synthesized reference materials. The major metabolic pathways described within this study (monoand bis-O-demethylation, hydroxylation at different positions, and combinations thereof, followed by the glucuronidation, sulfation, and/or $N$-acetylation of primary metabolites) generally correspond to the results of previously reported metabolism of several other NBOMes. The cyano functional group was either hydrolyzed to the respective amide or carboxylic acid or remained untouched. Differences between species should be taken into account in studies of the metabolism of novel substances.

Keywords: 25CN-NBOMe; LC-MS; metabolite synthesis; metabolomics

\section{Introduction}

2,5-Dimethoxy-4-(2-((2-methoxybenzyl)amino)ethyl)benzonitrile (25CN-NBOMe) is a novel psychoactive substance (NPS) belonging to the extensive $N$-2-methoxybenzyl (NBOMe) family, the structure of which emerges from the renowned 2,5-dimethoxyphenethylamines functionalized at the 4-position (2C-X).

The unprecedented and intriguing discovery that benzylation of the aminic nitrogen of 2C-X can lead to potently biologically active compounds [1] opened a broad scene for expansive, hitherto unexplored realms in the world of psychoactive drugs, and inevitably prompted comprehensive research endeavors investigating plethora analogs.

Efforts in the pursuit of novel diagnostic, therapeutic, and research tools resulted in several notable implementations of $N$-benzylphenethylamines (NBPEAs), such as utilization of 2-(4-bromo-2,5-dimethoxyphenyl)- $\mathrm{N}$-(2-methoxybenzyl)ethan-1-amine (25B$\mathrm{NBOMe}$ ) as a positron emission tomography (PET) radiolabeled tracer known as $\left[{ }^{11} \mathrm{C}\right] \mathrm{Cimbi}-$ 36 , which has been used for visualization and quantification of serotonin 2A (5-HT2A) 
receptor in the human brain [2,3], or the discovery of 4-(2-((2-hydroxybenzyl)amino)ethyl)2,5-dimethoxybenzonitrile $(25 \mathrm{CN}-\mathrm{NBOH})$ as one of the most selective agonist ligands for the 5-HT2A receptor known to date [4-6].

Explorational research has been thoroughly carried out also behind the doors of academic and clinical laboratories, spawning spates of novel analogs of the immense theoretical structural variety, often not yet recorded in literature. Some of them materialized, flooding the NPS market since $2010[7,8]$, and NBPEAs are now well-established street drugs at many places around the world [9].

Due to their current potential uses in many domains of interest, pharmacological and toxicological characterizations of NBPEAs, as well as an understanding of their metabolism, are necessary.

In the past, a significant correlation between 5-HT2 receptor affinity and potency of several hallucinogenic substances in rats was observed $[10,11]$. Currently, agonism at the 5-HT2A receptor is a major factor believed to be important and implicated in mediating the subjective and mind-altering effects of a drug of the "classical psychedelic" classes [12-15]. Since $\mathrm{N}$-benzylation of 2C-X compounds dramatically enhances their 5-HT2A receptor affinity and improves selectivity over other 5-HT receptor subtypes [1,16-21], NBPEAs represent an intriguing investigational aim. Compared to classical $2 \mathrm{C}-\mathrm{X}$ compounds, NBOMes often exhibit subnanomolar affinities for the 5-HT2 receptors, along with increased binding affinity at serotonergic 5-HT2A, 5-HT2C, adrenergic alpha1, dopaminergic D1-3, and histaminergic $\mathrm{H} 1$ receptors, monoamine transporters, and reduced binding to 5-HT1A receptors and trace amine-associated receptor 1 (TAAR1) [21]. However, NBOMes are substantially weaker in functional assays at the 5-HT2A receptor than their 2C-X counterparts [20]. The binding profiles of NBPEAs predict strong hallucinogenic effects in humans similar to lysergic acid diethylamide (LSD), possibly with increased stimulant action due to alpha1 adrenergic interactions [21]. Head twitch response (HTR) assays in mice, currently widely used laboratory animal behavioral proxy for 5-HT2A receptor-mediated hallucinogenic effects in humans [22-24], have also shown high potency of NBPEAs [25,26]. The in vitro characteristics and animal behavioral assays correlate with their potency known from their recreational uses [9]. The narrow pharmacological-toxicological window makes NBPEAs potentially dangerous substances if mistaken for other relatively safe drugs such as LSD [27,28]. In overdose amounts, NBOMes have been anecdotally reported to occasion acute sympathomimetic and cardiovascular toxicity [9].

Findings from different metabolic studies of 25I-NBOMe [29-31], 25B-NBOMe, and 25C-NBOMe [32] thus far tentatively indicate similarities in the extensive metabolic pathways of NBOMe compounds. Primary metabolites are 5-O-desmethyl-25X-NBOMe, 2$\mathrm{O}$-desmethyl-25X-NBOMe, 25X-NBOH, and their glucuronic acid conjugates, along with a large array of minor metabolites, such as $\mathrm{N}$-debenzylation $(2 \mathrm{C}-\mathrm{X})$, or ring- or chainhydroxylation [29-31,33-41]. The major cytochrome P450s responsible for biotransformation of these compounds have been identified as CYP3A4, CYP2C9, CYP2C19, CYP1A2, CYP2B6 [33,42].

The average intrinsic clearance is higher for NBOMes compared to 2C-X (6.0 [1.9-14.0] and $0.51 \mathrm{~L} / \mathrm{kg} / \mathrm{h}$, respectively), predictive of high first-pass metabolism in the liver [36]. These findings correlate with their lack of peroral bioavailability-the most commonly employed routes of administration of powdered or liquid NBOMes being sublingual, buccal, or intranasal [43].

The synthesis of 25CN-NBOMe was first published in the literature in 2010 among a series of tenths of compounds with structural variations, determining their effects on receptor binding affinities and functional activities at 5-HT2A and 5-HT2C receptors [4,5].

Besides these preliminary in vitro characteristics, no data are available on the animal and human absorption, distribution, metabolism, and excretion (ADME) properties of $25 \mathrm{CN}-\mathrm{NBOMe}$, partly due to the ethical and legal concerns associated with their use. In the light of the increasing use of NBOMes in research and recreation, there is an urgent 
need for controlled experiments identifying the pharmacological properties, identifying metabolites, and establishing potential drug-drug interactions of this novel compound.

Here, we present a study establishing the in vitro and in vivo metabolism of $25 \mathrm{CN}$ NBOMe, analyzing its phase I and phase II metabolites in rats, human liver microsomes (HLM), and Cunninghamella elegans (C. elegans) fungus mycelium with the confirmation of the most abundant metabolites by the synthesis of their reference standards.

\section{Results and Discussion}

\subsection{Untargeted Screening and Detection Of Metabolites}

First, an untargeted screening approach was applied to predict major metabolic pathways. Rat urine, human liver microsomes, and C. elegans culture medium samples were separated using reversed-phase high-performance liquid chromatography (RP HPLC), and both high-resolution mass spectrometry (HR-MS) only and high-resolution tandem mass spectrometry (HR-MS/MS) measurements were performed by a triple quadrupole time of flight instrument. 25CN-NBOMe phase I and II metabolites were identified based on the precursor ion exact masses (PM) and most abundant fragment ions (FI) in HR-MS/MS. All detected metabolites are summarized in Table 1.

Table 1. 25CN-NBOMe phase I and II metabolites, their protonated precursor ion exact masses and retention times (RT) detected in rat urine (RU), human liver microsomes (HLM), and C. elegans (CE). Data were measured with the UltiMate 3000 (Thermo) coupled to the TripleTOF 5600 (AB Sciex) LC-MS system.

\begin{tabular}{|c|c|c|c|c|c|c|}
\hline No. & Metabolite & $\begin{array}{c}\text { Precursor ion } \\
\text { Exact Mass }[\mathrm{m} / \mathrm{z}]\end{array}$ & RT [min] & RU & HLM & $\mathrm{CE}$ \\
\hline M1 & 25CN-NBOMe & 327.1709 & 7.9 & I & I & $\mathrm{I}$ \\
\hline M2 & hydroxy-25CN-NBOMe isomer 1 & 343.1658 & 7.4 & I & & \\
\hline M3 & hydroxy-25CN-NBOMe isomer 2 & 343.1658 & 7.3 & $\mathrm{I}$ & I & $\mathrm{I}$ \\
\hline M4 & hydroxy-25CN-NBOMe isomer 3 & 343.1658 & 7.7 & & $\mathrm{D}$ & \\
\hline M5 & dehydro-25CN-NBOMe & 325.1552 & 7.3 & $\mathrm{D}$ & $\mathrm{I}$ & \\
\hline M6 & dehydro-25CN-NBOMe-N-oxide & 341.1501 & 9.8 & $\mathrm{I}$ & & $\mathrm{D}$ \\
\hline M7 & dehydro-hydroxy-25CN-NBOMe & 341.1501 & 10.1 & & $\mathrm{D}$ & $\mathrm{I}$ \\
\hline M8 & O-demethyl-hydroxy-25CN-NBOMe & 329.1501 & 6.9 & $\mathrm{D}$ & $\mathrm{I}$ & \\
\hline M9 & O-demethyl-25CN-NBOMe & 313.1552 & 7.5 & I & I & I \\
\hline M10 & $25 \mathrm{CN}-\mathrm{NBOH}$ & 313.1552 & 7.6 & I & $\mathrm{I}$ & $\mathrm{I}$ \\
\hline M11 & O,O-bis-demethyl-25CN-NBOMe & 299.1396 & 6.8 & I & & \\
\hline M12 & O-demethyl-25CN-NBOH & 299.1396 & 7.1 & I & I & $\mathrm{D}$ \\
\hline M13 & O,O-bis-demethyl-hydroxy-25CN-NBOMe isomer 1 & 315.1345 & 5.8 & $\mathrm{D}$ & & \\
\hline M14 & O,O-bis-demethyl-hydroxy-25CN-NBOMe isomers $2,3,4$ & 315.1345 & $6.1-6.8$ & $\mathrm{D}$ & & \\
\hline M15 & O-demethyl-dehydro-hydroxy-25CN-NBOMe & 327.1345 & 9.2 & $\mathrm{D}$ & & \\
\hline M16 & O,O-bis-demethyl-dehydro-25CN-NBOMe & 297.1239 & 6.9 & $\mathrm{D}$ & & \\
\hline M17 & O,O-bis-demethyl-25CN-NBOH & 285.1239 & 5.7 & $\mathrm{D}$ & & \\
\hline M18 & $2 \mathrm{C}-\mathrm{CN}$ & 207.1134 & 5.7 & $\mathrm{I}$ & $\mathrm{I}$ & I \\
\hline M19 & O-demethyl-2C-CN & 193.0977 & 4.9 & I & $\mathrm{D}$ & \\
\hline M20 & O-demethyl-deamino-hydroxy-2C-CN & 194.0817 & 6.0 & $\mathrm{D}$ & & \\
\hline M21 & O-demethyl-deamino-carboxy-2C-CN & 208.0610 & 5.7 & $\mathrm{I}$ & & \\
\hline M22 & $2 \mathrm{C}-\mathrm{CONH}_{2}-\mathrm{NBOMe}$ & 345.1814 & 7.1 & & & $\mathrm{D}$ \\
\hline M23 & O-demethyl-2C-CONH 2 & 211.1078 & 4.0 . & $\mathrm{D}$ & & \\
\hline M24 & O,O-bis-demethyl-hydroxy-2C-COOH-NBOMe & 334.1291 & 5.4 & $\mathrm{D}$ & & \\
\hline M25 & $2 \mathrm{C}-\mathrm{COOH}$ & 226.1079 & 4.5 & $\mathrm{D}$ & & \\
\hline M8I G & O-demethyl-hydroxy-25CN-NBOMe glucuronide isomer 1 & 505.1822 & 6.2 & I & & \\
\hline M8 G & O-demethyl-hydroxy-25CN-NBOMe glucuronide isomer 2 & 505.1822 & 6.7 & $\mathrm{D}$ & & \\
\hline M9 G & O-demethyl-25CN-NBOMe glucuronide & 489.1873 & 6.9 & I & $\mathrm{D}$ & \\
\hline M11 G & O,O-bis-demethyl-25CN-NBOMe glucuronide & 475.1717 & 6.1 & I & $\mathrm{D}$ & \\
\hline M13 G & O,O-bis-demethyl-hydroxy-25CN-NBOMe glucuronide isomer 1 & 491.1666 & 5.4 & $\mathrm{D}$ & & \\
\hline M14 G & O,O-bis-demethyl-hydroxy-25CN-NBOMe glucuronide isomer 2 & 491.1666 & 6.2 & $\mathrm{D}$ & & \\
\hline M16 G & O,O-bis-demethyl-dehydro-25CN-NBOMe glucuronide & 473.1560 & 5.6 & $\mathrm{D}$ & & \\
\hline M17 G & O,O-bis-demethyl-25CN-NBOH glucuronide & 461.1560 & 5.4 & I & & \\
\hline M19 G & O-demethyl-2C-CN glucuronide & 369.1298 & 4.0 & $\mathrm{D}$ & & \\
\hline M26 G & oxo-2C-CN glucuronide & 397.1247 & 4.5 & $\mathrm{D}$ & & \\
\hline M3 S & hydroxy-25CN-NBOMe sulfate & 423.1226 & 7.4 & $\mathrm{D}$ & & \\
\hline M8 S & O-demethyl-hydroxy-25CN-NBOMe sulfate & 409.1069 & 6.9 & I & & \\
\hline M9S & O-demethyl-25CN-NBOMe sulfate & 393.112 & 7.7 & $\mathrm{D}$ & & \\
\hline M11 S & O,O-bis-demethyl-25CN-NBOMe sulfate & 379.0964 & 6.9 & I & & \\
\hline M12 S & O-demethyl-25CN-NBOH sulfate & 379.0964 & 7.1 & $\mathrm{D}$ & & \\
\hline M13 S & O,O-bis-demethyl-hydroxy-25CN-NBOMe sulfate isomer 1 & 395.0913 & 5.8 & $\mathrm{D}$ & & \\
\hline
\end{tabular}


Table 1. Cont.

\begin{tabular}{|c|c|c|c|c|c|c|}
\hline No. & Metabolite & $\begin{array}{c}\text { Precursor ion } \\
\text { Exact Mass }[\mathrm{m} / \mathrm{z}]\end{array}$ & RT [min] & RU & HLM & $\mathrm{CE}$ \\
\hline M14 S1 & O,O-bis-demethyl-hydroxy-25CN-NBOMe sulfate isomer 2 & 395.0913 & 6.3 & $\mathrm{D}$ & & \\
\hline M14 S2 & O,O-bis-demethyl-hydroxy-25CN-NBOMe sulfate isomer 3 & 395.0913 & 6.8 & $\mathrm{D}$ & & \\
\hline M17 S1 & O,O-bis-demethyl-25CN-NBOH sulfate isomer 1 & 365.0807 & 5.7 & $\mathrm{D}$ & & \\
\hline M17 S2 & O,O-bis-demethyl-25CN-NBOH sulfate isomer 2 & 365.0807 & 6.4 & $\mathrm{D}$ & & \\
\hline M26 S & oxo-2C-CN sulfate & 301.0494 & 5.0 & $\mathrm{I}$ & & \\
\hline M19 Ac & O-demethyl-2C-CN N-acetyl isomer 1 & 235.1083 & 7.1 & I & & \\
\hline M19 Ac & O-demethyl-2C-CN N-acetyl isomer 2 & 235.1083 & 7.3 & I & & \\
\hline M19 Ac G & O-demethyl-2C-CN N-acetyl glucuronide & 411.1404 & 5.9 & I & & \\
\hline M19 Ac S & O-demethyl-2C-CN N-acetyl sulfate & 315.0651 & 6.2 & $\mathrm{D}$ & & \\
\hline M27 Ac & hydroxy-2C-CN N-acetyl & 265.1188 & 5.6 & $\mathrm{D}$ & & \\
\hline
\end{tabular}

$\mathrm{I}=$ identified by matching precursor ion mass and recorded HR-MS/MS spectrum; D = detected based on the precursor ion exact mass only.

Altogether twenty-seven phase I metabolites and twenty-six phase II metabolites were detected. In most cases, their chemical structures were proposed based on recorded HRMS/MS spectra. The exact masses of most abundant fragment ions are listed in Table S1 in Supplementary data. Following the classification used by Caspar et al. [31], for compound identification, the accurate precursor ion has to be detectable and the underlying HRMS/MS spectrum has to fit with the reference spectrum. For detection, only the accurate precursor ion has to be detectable. In a case, when a reference MS/MS spectrum was not available, at least the main peaks in obtained HR-MS/MS spectrum were assigned to particular fragment ions. Herein, only the typical fragment ions used for the identification of the metabolites will be discussed in detail to illustrate the main fragmentation patterns.

The $\mathrm{MS}^{2}$ spectrum of 25CN-NBOMe (M1; PM at $m / z$ 327.1709, M + H) showed similar fragmentation as previously described in metabolic studies of halogenated NBOMes, 25I-NBOMe [29,31,33] and 25B- and 25C-NBOMes [32]. The major FIs correspond to the cleavage of the methoxybenzyl moiety (at $m / z$ 121.0653) and tropylium ion (at $m / z$ 91.0548) formed after the loss of the methoxy group (-30.0105). The FI representing the $2 \mathrm{C}$ part bearing the amino group $(\mathrm{m} / \mathrm{z} 207.1134)$ was not detected under the experimental conditions.

The most abundant metabolites were formed as a result of $O$-demethylation of either of the methoxy groups, hydroxylation at the aromatic ring, or even at the alkyl chain and a combination thereof. $N$-Demethoxybenzylation represented relatively little deployed metabolic pathway. Hereby, we also report the conversion of the cyano group to the corresponding amide or carboxylic acid. In all matrices, the most prevalent phase I metabolites were the same: mono- and bis-O-demethylated products, hydroxylated products, and $2 \mathrm{C}-\mathrm{CN}$ together with its deamino-hydroxylated counterpart. To identify the exact positions of present functional groups and to confirm the proposed metabolic pathways, reference standards of the metabolites were synthesized.

\subsection{Synthesis of Reference Standards}

Based on the untargeted analysis, the most abundant metabolites were chosen, and their structures were proposed in accordance with their fragmentation in HR-MS/MS. The selected compounds were synthesized as reference standard materials (Figures 1 and 2).

All synthesized standards (Figure 2, compounds 6, 8, 9, 11, 12, and 13) of expected major metabolites of $25 \mathrm{CN}-\mathrm{NBOMe}$ were fully characterized $\left({ }^{1} \mathrm{H}\right.$ and ${ }^{13} \mathrm{C}$ NMR, HR-MS, melting point) and their HR-MS/MS spectral data were compared to those obtained in the untargeted analysis. 


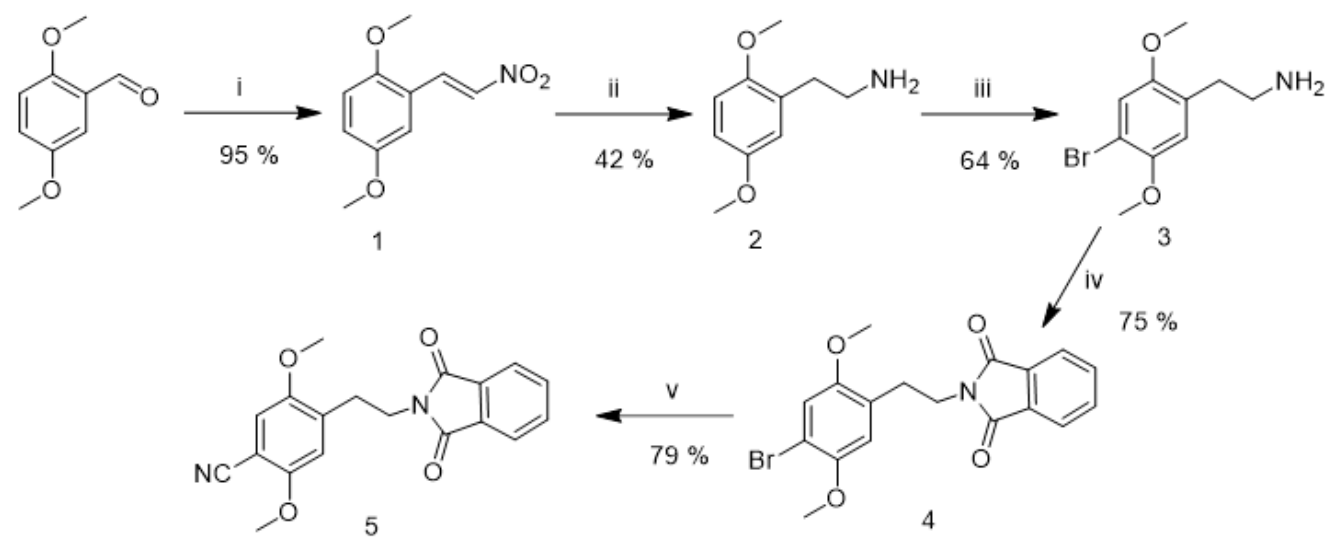

Figure 1. Synthetic route to the cyanide precursor. i. $\mathrm{CH}_{3} \mathrm{NO}_{2}, \mathrm{IPA}, \mathrm{EDDA}$; ii. Red-Al ${ }^{\circledR}$, THF; iii. $\mathrm{Br}_{2}, \mathrm{AcOH}$; iv. Phthalic anhydride, DMF, reflux; v. CuCN, DMF.

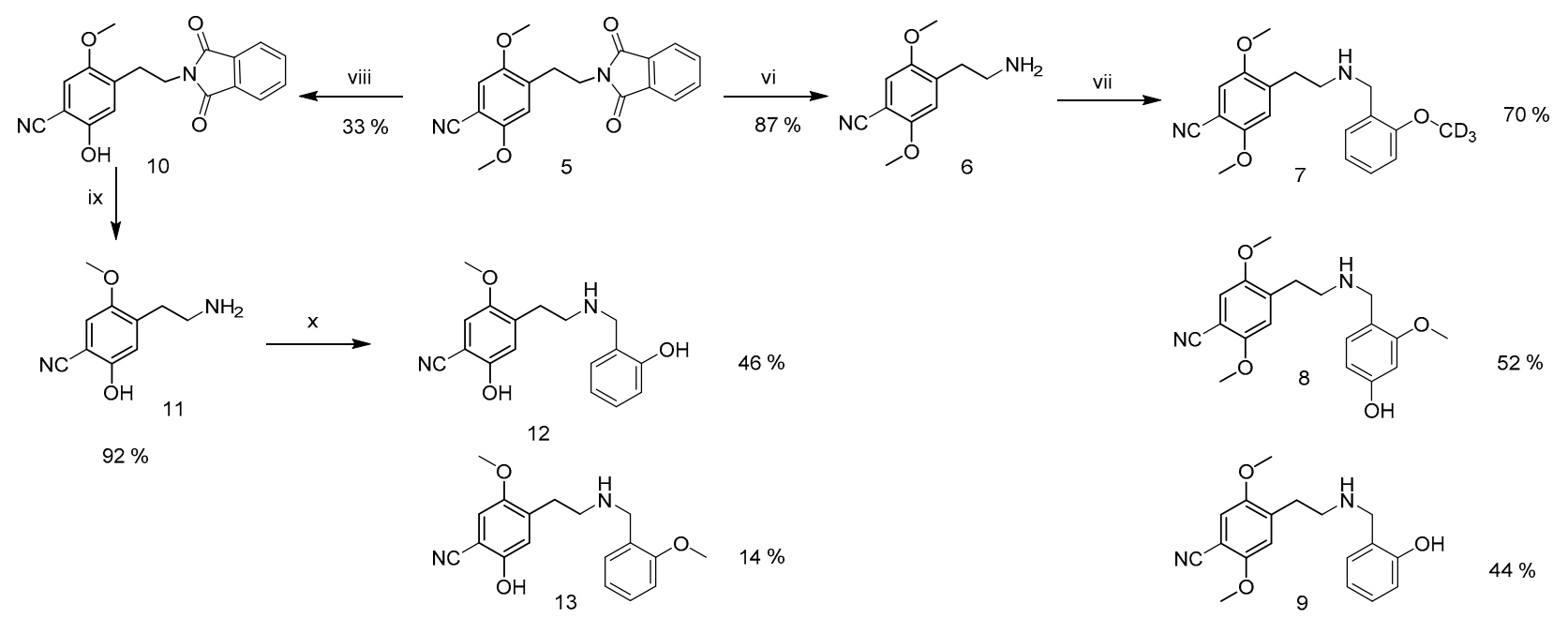

Figure 2. Synthesis of $25 \mathrm{CN}-\mathrm{NBOMe}$ and its most abundant metabolites. vi. (a) $\mathrm{NaBH}_{4}, \mathrm{IPA}, \mathrm{H}_{2} \mathrm{O}$ (b) AcOH, reflux; vii. (a) aldehyde (7 2-methoxy-d $\mathrm{d}_{3}$-benzaldehyde; 8 4-hydroxy-2-methoxybenzaldehyde; 9 salicylaldehyde), $\mathrm{EtOH}(\mathrm{b}) \mathrm{NaBH}_{4}$; viii. $\mathrm{BBr}_{3} 1.1$ eq., $\mathrm{DCM},-79{ }^{\circ} \mathrm{C}$ to $20^{\circ} \mathrm{C}$; ix. (a) $\mathrm{NaBH}_{4}, \mathrm{IPA}, \mathrm{H}_{2} \mathrm{O}$, (b) $\mathrm{AcOH}$, reflux; x. (a) aldehyde (12 salicylaldehyde; 13 2-methoxy-benzaldehyde), $\mathrm{EtOH} \mathrm{Et}_{3} \mathrm{~N}$, (b) $\mathrm{NaBH}_{4}$.

\subsection{LC-MS Analysis of the Most Abundant Metabolites}

All synthesized metabolites were confirmed in rat urine and human liver microsomes, in Cunninghamella elegans culture medium O-demethyl-2C-CN (11) was not detected. Measured HR-MS/MS and MS ${ }^{3}$ data not only allowed structure confirmation but also provided deeper insight into 25CN-NBOMe's metabolic fate and fragmentation patterns of individual metabolites.

Besides 25CN-NBOMe itself, two mono-O-demethylated metabolites were prepared as reference standards. The metabolite demethylated on the $2 \mathrm{C}$ moiety, $\mathrm{O}$-demethyl-25CNNBOMe (M9; PM at $m / z$ 313.1552, M + H), was assigned as 2-hydroxy-5-methoxy-4-\{2[(2-methoxybenzyl)amino]ethyl\}benzonitrile (13). It showed fragmentation typical for the whole group of metabolites bearing unchanged $N$-methoxybenzyl (NBOMe) moiety, with major FIs corresponding to the cleavage of this moiety (at $\mathrm{m} / \mathrm{z}$ 121.0653) and to subsequently formed tropylium ion (at $m / z$ 91.0548). The latter FI was accompanied by its hydrogenated counterpart (at $m / z$ 93.07043) formed under certain experimental conditions. For the other O-demethylated metabolite, 25CN-NBOH (9) (M10; PM at $\mathrm{m} / z$ 313.1552, $\mathrm{M}+\mathrm{H}$ ), the prominent FI corresponded to the cleavage of hydroxybenzyl moiety (at $m / z$ 107.0497). However, FIs representing the $2 \mathrm{C}$ part of the molecule showed comparable abundances. FIs 
were detected at $m / z$ 207.1134, 190.0868, and 175.0633 representing protonated 2C-CN, an ion formed by loss of ammonia and by the subsequent loss of a methyl radical, respectively.

O,O-bis-demethylated metabolite, O-demethyl-25CN-NBOH (12) (M12; PM at $\mathrm{m} / z$ 299.1396; $\mathrm{M}+\mathrm{H}$ ) showed a similar fragmentation pattern with most abundant FIs registered at $m / z 193.0977$ and 176.0712 corresponding to 2C primary amine yielded by hydroxybenzyl cleavage and subsequent loss of ammonia. Cleaved methoxybenzyl ion was also detected at $m / z 107.0497$.

In $\mathrm{MS}^{2}$ spectra of the $N$-demethoxybenzylated metabolites $2 \mathrm{C}-\mathrm{CN}(6 ; \mathrm{PM}$ at $\mathrm{m} / \mathrm{z}$ 207.1134, $\mathrm{M}+\mathrm{H}$ ) and its $O$-demethylated derivative $11(\mathrm{M} 19, \mathrm{PM}$ at $\mathrm{m} / \mathrm{z}$ 193.0977), the main FIs were formed by amine shift (FI at $m / z 190.0868$ for $2 \mathrm{C}-\mathrm{CN}$ and at $m / z 176.0712$ for O-demethyl-2C-CN), followed by loss of a methyl radical (FI at $m / z 175.0633$ for 2C-CN and at $m / z 161.0477$ for $O$-demethyl-2C-CN).

One of three detected mono-hydroxy-25CN-NBOMe isomers was assigned as $4^{\prime}$ hydroxy-25CN-NBOMe (M2, PM at $m / z$ 343.1658) by comparison with the synthesized reference standard (8). Its fragmentation was typical for the whole group of compounds hydroxylated at the aromatic ring of NBOMe moiety, with the most abundant FIs corresponding to the cleavage of the modified NBOMe moiety (at $m / z 137.0603$ ) and to subsequently formed tropylium ion bearing the hydroxy group (at $m / z$ 107. 0497). FIs representing the $2 \mathrm{C}$ part of the molecule were also present in the MS/MS spectrum and comprised ions detected at $m / z$ 207.1134, representing 2C primary amine yielded by cleavage of modified NBOMe moiety, and at $m / z$ 190.0868, formed by the subsequent loss of ammonia.

The most abundant first-order fragment ions of all synthesized metabolites were separated and further fragmented in a linear ion trap (LIT) of a triple quadrupole linear ion trap instrument. Both first and second-order fragments of individual 25CN-NBOMe metabolites are listed in Table 2. Based on identified transitions, a quantitative scan-free MS3 method [44] was developed to estimate the number of metabolites formed in vitro and in vivo experiments and to discuss the inter-species differences in 25CN-NBOMe metabolism. Results of quantification are graphically summarized in Figure 3.

Table 2. 25CN-NBOMe and its most abundant metabolites, protonated precursor ions, characteristic $\mathrm{MS}^{2}$, and $\mathrm{MS}^{3}$ fragment ions, retention times (RT), and detectability in rat urine (RU), human liver microsomes (HLM), and C. elegans culture media (CE). Data were measured with the UltiMate 3000 (Thermo) coupled to the QTrap 6500 (AB Sciex) LC-MS system.

\begin{tabular}{|c|c|c|c|c|c|c|}
\hline No. & Target Metabolite & $\begin{array}{c}\text { Precursor Ion } \\
{[\mathrm{m} / z]}\end{array}$ & $\begin{array}{l}\text { MS }^{2} \text { Fragment } \\
\text { Ions }[m / z]^{1}\end{array}$ & $\begin{array}{c}\text { MS }^{3} \text { Fragment } \\
\text { Ions }[m / z]^{1}\end{array}$ & $\begin{array}{c}\mathrm{RT} \\
{[\mathrm{min}]}\end{array}$ & $\begin{array}{l}\text { Detected } \\
\text { in Sample }\end{array}$ \\
\hline M1 & 25CN-NBOMe & 327 & $\begin{array}{c}77(1), 91(37) \\
93(13), 121(100) \\
205(2)\end{array}$ & $\begin{array}{l}\text { 121: } 77(8), 91(100), \\
93(83), 121(60) \\
\text { 205: } 175(31), \\
190(79), 205(100)\end{array}$ & 8.3 & RU, HLM, CE \\
\hline M2 & $\begin{array}{l}\text { hydroxy-25CN- } \\
\text { NBOMe } 1 \text { (8) }\end{array}$ & 343 & $\begin{array}{l}107(8), 137(100), \\
175(1), 190(30) \\
207(30)\end{array}$ & $\begin{array}{c}\text { 190: } 163(1), 175(21) \\
190(100) \\
\text { 207: } 147(1), 160(3), 163(1), \\
175(100)\end{array}$ & 7.8 & RU, HLM, CE \\
\hline M9 & $\begin{array}{l}\text { O-demethyl-25CN- } \\
\text { NBOMe (13) }\end{array}$ & 313 & $\begin{array}{c}91(14), 93(6) \\
121(100), 150(7) \\
312(9)\end{array}$ & $\begin{array}{c}\text { 91: } 65(100), 91(65), 93(97) \\
\text { 121: } 77(8), 91(88) \\
93(100), 121(34)\end{array}$ & 7.9 & RU, HLM, CE \\
\hline M10 & 25CN-NBOH (9) & 313 & $\begin{array}{c}77(44), 79(50), \\
106(100), 160(5), \\
175(78), 190(98), \\
207(85), 313(7)\end{array}$ & $\begin{array}{c}\text { 190: } 160(5), 175(100), \\
190(3) \\
\text { 207: } 190(100), 175(10), \\
207(2)\end{array}$ & 8.0 & RU, HLM, CE \\
\hline M12 & $\begin{array}{l}\text { O-demethyl-25CN- } \\
\text { NBOH (12) }\end{array}$ & 299 & $\begin{array}{c}77(4), 79(5), \\
107(42), 161(2), \\
176(67), 193(100), \\
299(22)\end{array}$ & $\begin{array}{c}\text { 176: } 121(1), 148(1), \\
149(2), 161(16), 176(100) \\
\text { 193: } 149(2), 161(14), 176 \\
(100), 193(93)\end{array}$ & 7.5 & RU, HLM, CE \\
\hline
\end{tabular}


Table 2. Cont.

\begin{tabular}{|c|c|c|c|c|c|c|}
\hline No. & Target Metabolite & $\begin{array}{c}\text { Precursor Ion } \\
{[\mathrm{m} / \mathrm{z}]}\end{array}$ & $\begin{array}{l}\text { MS }^{2} \text { Fragment } \\
\text { Ions }[m / z]^{1}\end{array}$ & $\begin{array}{l}\text { MS }^{3} \text { Fragment } \\
\text { Ions }[\mathrm{m} / \mathrm{z}]^{1}\end{array}$ & $\begin{array}{c}\text { RT } \\
\text { [min] }\end{array}$ & $\begin{array}{l}\text { Detected } \\
\text { in Sample }\end{array}$ \\
\hline M18 & $2 \mathrm{C}-\mathrm{CN}(6)$ & 207 & $\begin{array}{c}105(5), 133(6), \\
147(7), 160(23), \\
175(100), 190(85)\end{array}$ & $\begin{array}{c}\text { 175: } 104(1), 132(1), \\
\text { 160 (100), } 175(16) \\
\text { 190: } 117(1), 147(1), \\
160(5), 175(100), 190(2)\end{array}$ & 6.3 & RU, HLM, CE \\
\hline M19 & $\begin{array}{c}\text { O-demethyl-2C-CN } \\
\text { (11) }\end{array}$ & 193 & $\begin{array}{c}91(2), 118(3), \\
121(2), 133(4), \\
148(10), 161(92) \\
176(100)\end{array}$ & $\begin{array}{c}\text { 161: } 132(2), 160(14), \\
161(100) \\
\text { 176: } 148(2), 149(2), \\
161(15), 176(100)\end{array}$ & 5.5 & RU, HLM \\
\hline
\end{tabular}

${ }^{1}$ Relative intensity of fragment ion is given in brackets [\%].

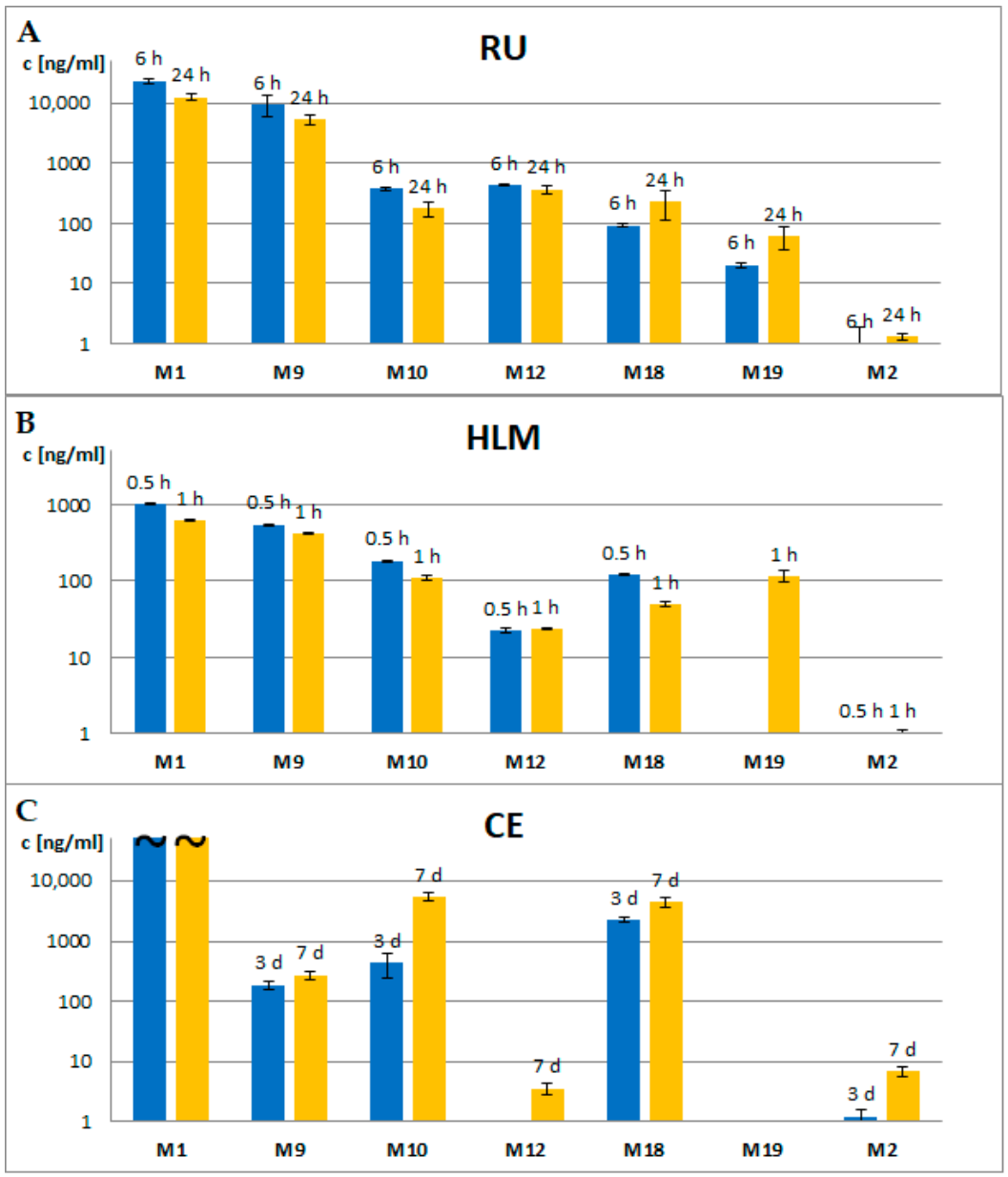

Figure 3. Comparison of concentration of individual 25CN-NBOMe metabolites in (A) rat urine (RU), (B) human liver microsome incubation (HLM) and (C) C. elegans culture media (CE) samples.

\subsection{Comparison of Metabolite Formation In Vitro and In Vivo and in Different Species}

Varying results of metabolite formation were discovered in the three approaches used in this study. After subcutaneous injection of a relatively high dose of $25 \mathrm{CN}-\mathrm{NBOMe}$ solution to rats, their urine was collected after $6 \mathrm{~h}$ and $24 \mathrm{~h}$. The dose of $50 \mathrm{mg} \cdot \mathrm{kg}^{-1}$ was selected according to the potency of related compounds, after it was proved to be safe for in vivo experiments using Modified Acute Toxicity assessment (OECD no. 423, 2001). Rat urine samples were generally rich in metabolites with twenty-four I phase and twenty-six II phase metabolites. The concentration levels of confirmed metabolites were also highest in this matrix. In vitro incubation of human liver microsomes produced similar phase I metabolites, just less in number and amount. In two cases, microsomes formed isomers hydroxylated in different positions compared to those found in rat urine 
(M4, M7). Even though monitoring of phase II metabolism in microsomes was not the original aim of this study, two glucuronidated metabolites (M9 G, M11 G) were found at low concentrations in microsomal samples. A uridine glucuronide transferase (UGT) is present in microsomes, as well as a limited amount of co-substrate (uridine $5^{\prime}$-diphosphoalpha-D-glucuronic acid) and co-factor $\left(\mathrm{MgCl}_{2}\right)$ necessary for the optimal activity of the enzyme. Therefore, we presume the original supply of co-factors was consumed for the glucuronidation, and then the reaction catalyzed by UGT stopped, as the addition of critical co-factors was not included in our incubation protocol. C. elegans released only eight phase I metabolites formed by the most widespread metabolic transformations of 25X-NBOMe substances. From quantitative measurements, it was obvious that the extent of $O$-demethylation at the NBOMe part was reduced compared to other studied systems. On the other hand, the concentration of formed 2C-CN (M18) was relatively high and the amide derivative of parent drug M22, not found in any other matrix, was also detected in C. elegans culture medium.

\subsection{Proposed Metabolic Pathways}

Based on the metabolites identified in rat urine, human liver microsomes and fungus mycelium (summarized in Table 1), metabolic pathways of 25CN-NBOMe can be proposed.

Analogously to the previously published metabolic studies of halogenated NBOMes [29,32,33], 25CN-NBOMe undergoes the same major metabolic steps. The most abundant metabolites are the result of $\mathrm{O}$-demethylation, $\mathrm{O}$-bis-demethylation, and $\mathrm{O}$ demethylation plus hydroxylation. $N$-Demethoxybenzylation represented relatively little deployed pathway. Hereby described is the newly found varying metabolism of cyano group to the corresponding amide or carboxylic acid, or its metabolic stability.

Phase I pathways were found to be mono-demethylation (M9, M10), bis-demethylation (M11, M12), and tris-demethylation (M17) of the methoxy groups, mono-hydroxylation (M2, M3, M4), N-demethoxybenzylation (M18), combinations of mono-demethylation with mono-hydroxylation (M8), bis-demethylation with mono-hydroxylation (M13, M14), or $N$-demethoxybenzylation with mono-demethylation (M19), followed by oxidative deamination (M20) and oxidation to a carboxylic acid (M21). Compared to the metabolism of analogous halogenated NBOMes [29,32,33], bis-hydroxylation, bis-hydroxylation with mono-demethylation, or the oxidation of the $\mathrm{N}$-demethoxybenzylated $2 \mathrm{C}-\mathrm{CN}$ to amide was not seen for 25CN-NBOMe.

Based on previously published discoveries in the metabolism of 25I-NBOMe, identifying hydroxylation in the benzylic para-position (4'-OH-25I-NBOMe) as the major metabolite [33], 4'-OH-25CN-NBOMe (8) was analogously synthesized as a reference standard. Although this metabolite was found (M2) and confirmed in our analysis, it is, however, not the most abundant isomer of benzylic mono-hydroxylation.

Several dehydrogenated-metabolites with the resulting double bond located at the 2C-moiety linker were found (M5, M6, M7, M15, M16). Dehydrogenation was previously detected in the metabolism of 25I-NBOMe and 25I-NBOH by Nielsen et al. [33] and of 25Band 25C-NBOMe by Caspar et al. [32], while noting the dehydration could be possibly caused by artificial dehydroxylation under the analytical conditions of corresponding metabolites hydroxylated on ethyl-linker via unstable hemiaminals [32].

Two hydroxylated metabolites (M7 and M15) showed atypical chromatographic behavior, as they were eluted later than the parent compound and the appropriate $N$-oxide M6 on a reversed-phase column. In both cases, the metabolite's polarity was reduced by the formation of an intramolecular hydrogen bond between the oxygens of the hydroxy group in the benzylic position and the methoxy group in NBOMe part of the molecule, causing the usual retention of the compounds.

Previously unreported is the metabolic fate of the cyano-functional group within the NBOMe scaffold. Based on the findings of in vitro metabolism of aromatic nitriles by rat liver subcellular fractions [45], two possible pathways were suggested. First is the direct conversion of the nitrile group to carboxylic acid and ammonia by nitri- 
lase. The second pathway involves nitrile hydratase forming an amide followed by amidase forming carboxylic acid and ammonia. In our present study of the metabolism of $25 \mathrm{CN}-\mathrm{NBOMe}$, conversion of nitrile to amide was observed in rat urine and mycelium (metabolite M22 as a result of nitrile hydrolysis and M23 as a result of nitrile hydrolysis combined with $\mathrm{N}$-demethoxybenzylation and $\mathrm{O}$-demethylation), whereas conversion to carboxylic acid was detected only in the samples of rat urine (metabolites M24 combined with bis-demethylation and mono-hydroxylation and M25 in combined with $\mathrm{N}$ demethoxybenzylation) (Table 1). The fungus species likely contain only nitrile hydratase, but not amidase, and metabolism is therefore finished at the amide stage. An important discovery is that the cyano group remained completely unmetabolized by human liver microsomes in our experiments, suggesting there are no enzymes to convert this functional group present.

Phase II metabolism was predominant in rat urine samples, where several metabolites were formed by glucuronidation (G), sulfation (S) and/or N-acetylation (Ac) of phase I metabolites. Two metabolites were detected only in their conjugated forms, namely oxo-2C-CN glucuronidate (M26 G) and sulfate (M26 G), and hydroxy-2C-CN N-acetyl (M27 Ac).

\section{Materials and Methods}

\subsection{In Vitro Incubations with Human Liver Microsomes}

Cryopreserved $\left(-80{ }^{\circ} \mathrm{C}\right)$ primary human liver microsomes (kept in the dark prior to use), pooled from 50 donors equally representing a true population sample and fully characterized for major cytochrome P450 activities and select Phase II enzymes, were used in this study (purchased from Thermo Fisher Scientific, Waltham, MA, USA) and used according to the recommendation and protocol from the manufacturer [46]. The microsomes were slowly thawed on ice. Then, a reaction mixture was prepared from $163 \mu \mathrm{L}$ of $100 \mathrm{mM}$ phosphate-buffered saline (PBS; pH 7.4), $2 \mu \mathrm{L}$ of $25 \mathrm{CN}-\mathrm{NBOMe}$ to a final concentration of $10 \mu \mathrm{M}$, and $25 \mu \mathrm{L}$ of $20 \mathrm{mg} \cdot \mathrm{mL}^{-1}$ of liver microsomes. The mixture was preincubated for $10 \mathrm{~min}$. at $37^{\circ} \mathrm{C}$ in a water bath. After that, the reactions were initiated by the addition of $10 \mu \mathrm{L}$ of freshly prepared $20 \mathrm{mM}$ nicotinamide adenine dinucleotide phosphate (NADPH) dissolved in 0.1M PBS. The samples were incubated for $0,15,30,45$, and $60 \mathrm{~min}$ at $37^{\circ} \mathrm{C}$ with gentle agitation. At each time point, the reactions were terminated by the addition of $200 \mu \mathrm{L}$ of ice-cold acetonitrile. Immediately after the quenching, the samples were frozen and kept at $-80^{\circ} \mathrm{C}$ till the MS analysis. Besides, four negative control samples were prepared: a no microsome sample, a no $25 \mathrm{CN}-\mathrm{NBOMe}$ sample, a no NADPH sample, and a sample with heat-activated microsomes (pretreatment at $45^{\circ} \mathrm{C}$ for $30 \mathrm{~min}$ ). Besides, to verify unaffected microsome metabolism, a positive control, was prepared using $10 \mu \mathrm{M}$ testosterone. The experiment was done in two independent replicates.

Commercially available human microsomes were used in this study. Human volunteers or donors, which requires the ethic committee or inform consent, were not involved.

\subsection{In Vitro Metabolism by Cunninghamella Elegans}

Modified protocol by Grafinger et al. [38] was used for the cultivation procedure. $C$. elegans (approx. $\left.1 \mathrm{~cm}^{2}\right)$ was inoculated on potato dextrose (PD) agar plates $\left(12 \mathrm{~g} \mathrm{~L}^{-1} \mathrm{PDB}\right.$, $5 \mathrm{~g} \mathrm{~L}^{-1}$ agar) (Formedium, Hunstanton, UK) in a 90-mm Petri dish and grown at $24^{\circ} \mathrm{C}$ in the dark for 10 days. The mycelial mat from one plate (i.e., approx. $58 \mathrm{~cm}^{2}$ of mycelium) was harvested with forceps into $10 \mathrm{~mL}$ of PD medium $\left(12 \mathrm{~g} \cdot \mathrm{L}^{-1} \mathrm{PDB}\right)$ and vigorously shaken for $1 \mathrm{~min}$. The homogenized mass was transferred into a $500 \mathrm{~mL}$ Erlenmeyer flask containing $35 \mathrm{~mL}$ of fresh PD medium. The mycelium was grown in a rotary shaker at $100 \mathrm{rpm}$ at $28^{\circ} \mathrm{C}$ in the dark for 3 days into a single large blob. Two controls-one containing PD medium and mycelium, the second containing only PD medium - were set up analogously. After three days, $1.5 \mathrm{~mL}$ of the medium from each of the three flasks was transferred to a plastic tube and stored at $-20^{\circ} \mathrm{C}$ until further analysis. 25CN-NBOMe $(50 \mathrm{mg})$ was resuspended in $4 \mathrm{~mL}$ sterile water with the help of a vortex. The final concentration of $25 \mathrm{CN}-\mathrm{NBOMe}$ 
solution was $270 \mu \mathrm{g} \cdot \mathrm{mL}^{-1}$. In a sterile tube, $3 \mathrm{~mL}$ of PD medium was mixed with $2 \mathrm{~mL}$ of $25 \mathrm{CN}-\mathrm{NBOMe}$ solution, or with $2 \mathrm{~mL}$ of sterile water as a control, and added to the respective mycelial culture in a flask, followed by $35 \mathrm{~mL}$ of fresh PD medium. The 3-day old culture of C. elegans (i.e., little less than $58 \mathrm{~cm}^{2}$ of mycelium) from PD agar plate was harvested with forceps, resuspended in $10 \mathrm{~mL}$ of fresh PD medium by vigorous shaking, and added to the mycelial culture. The cultures were mixed by swirling, and $1.5 \mathrm{~mL}$ of each was transferred to a plastic tube and stored at $-20^{\circ} \mathrm{C}$ until further analysis. Samples of the medium 24,48 , and $72 \mathrm{~h}$ after 25CN-NBOMe addition were drawn $(1.5 \mathrm{~mL}$ of each culture transferred into a plastic tube) and stored at $-20^{\circ} \mathrm{C}$ until further analysis. Seven days after 25CN-NBOMe addition, all mycelia were harvested. Medium (approx. $45 \mathrm{~mL}$ ) was poured into a sterile $50 \mathrm{~mL}$ tube, the mycelia were squished with sterilized forceps and transferred into a weighted $50 \mathrm{~mL}$ tube, and the rest of the medium poured into a new $50 \mathrm{~mL}$ tube. In the case of $25 \mathrm{CN}-\mathrm{NBOMe}-\mathrm{PD}$ control, approx. $50 \mathrm{~mL}$ of the medium was poured into the tube.

\subsection{Animals}

All animals were male outbred Wistar rats acquired from VELAZ (Prague, Czech Republic) weighing between 200-275 $\mathrm{g}$ at the beginning of testing. The rats were housed two per cage under a controlled temperature $\left(22 \pm 2{ }^{\circ} \mathrm{C}\right)$ and humidity $(30-70 \%)$ with food pellets and water ad libitum. 25CN-NBOMe was dissolved in physiological solution with Tween 20, and administered in a dose of $50 \mathrm{mg} \cdot \mathrm{kg}^{-1}$ subcutaneously (s.c.) in a volume of $2 \mathrm{~mL} \cdot \mathrm{kg}^{-1}$. After administration, the rats $(n=6)$ were placed in a metabolic chamber, and the urine was collected into a pre-cooled collector that maintained the temperature of $-4{ }^{\circ} \mathrm{C}$ for the following $24 \mathrm{~h}$. The collected urine was subsequently frozen and kept at $-80{ }^{\circ} \mathrm{C}$ until the analyses.

All procedures were conducted following the principles of laboratory animal care of the National Committee for the Care and Use of Laboratory Animals (Prague, Czech Republic), and Guidelines of the European Union (86/609/EU). The protocol was approved by the National Committee for the Care and Use of Laboratory Animals (Prague, Czech Republic) under the number: 59449/2016-MZE-17214.

\subsection{Synthesis and Characterization of the Most Abundant Metabolites \\ 3.4.1. General Information}

Chemicals used for the synthesis were obtained from commercial sources (Sigma Aldrich, St. Louis, MO, USA and Acros Organics, Geel, Belgium). Hexane, DCM, and EtOAc were acquired from commercial sources and were used after distillation. Molecular sieves were used to dry solvents denoted as dry. Other commercial reagents and solvents were used without further purification. The reactions were monitored with the aid of thin-layer chromatography (TLC Silica gel 60 F254) and pre-coated reverse-phase gel plates (TLC RP-18 F254). All operations involving air-sensitive reagents were performed under an inert atmosphere of dry argon and dried solvents. Melting points were determined using a melting point apparatus (PGH Rundfunk-Fernsehen, Niederdorf, Germany), and they are uncorrected. NMR spectroscopy was performed in $\mathrm{CD}_{3} \mathrm{OD}$ or DMSO at room temperature using a Varian Gemini $300 \mathrm{MHz}\left({ }^{1} \mathrm{H}\right.$ NMR $300 \mathrm{MHz},{ }^{13} \mathrm{C}$ NMR $75 \mathrm{MHz}$ ) and an Agilent $400 \mathrm{MR}$ DDR2 $\left({ }^{1} \mathrm{H}\right.$ NMR $400 \mathrm{MHz},{ }^{13} \mathrm{C}$ NMR $\left.100 \mathrm{MHz}\right)$. Preparative HPLC was performed using COMBIFLASH RF200 UV/VIS (Teledyne ISCO, Lincoln, NE, USA). An in-house made column was prepared by filling a cartridge with polar silica (Merck, Darmstadt, Germany) for normal phase HPLC. For reverse phase HPLC, the commercially available RediSep ${ }^{\circledR}$ Gold C18 column (Teledyne ISCO) was used.

\subsubsection{Experimental Details}

The synthetic route to the cyanide precursor is depicted in Figure 1. The preparation of amine 3 (2C-B) started with a Henry reaction between 2,5-dimethoxybenzaldehyde and nitromethane [47]. The nitrostyrene 1 was first reduced to amine 2 using Red-Al ${ }^{\circledR}$ [48] and 
brominated with elemental bromine in $\mathrm{AcOH}$ [49], yielding the amine 3 as $\mathrm{HBr}$ salt. A phthalimide 4 was prepared by heating freebase 3 with phthalic anhydride in DMF [50]. Finally, a phthalimide 5 was prepared from 4 using $\mathrm{CuCN}$ [50]. Syntheses of the metabolites are shown in scheme Figure 2.

4-(2-Aminoethyl)-2,5-dimethoxybenzonitrile (6)

Phthalimide 5 (336 mg, $1 \mathrm{mmol}$ ) was suspended in 2-propanol (24 mL) and water $(4 \mathrm{~mL})$. The mixture was cooled to $0^{\circ} \mathrm{C}$ and sodium borohydride $(256 \mathrm{mg}, 7 \mathrm{mmol})$ was added portion-wise for $5 \mathrm{~min}$. The mixture was allowed to warm to room temperature and stirred overnight. The next day glacial acetic acid $(4 \mathrm{~mL})$ was added dropwise for $5 \mathrm{~min}$ and the solution was refluxed for $5 \mathrm{~h}$. After cooling to room temperature, the solvent was evaporated in vacuo, and the residue was dissolved in $30 \mathrm{~mL}$ of water with $\mathrm{NaOH}$ $(4 \mathrm{~g})$ and extracted with DCM $(3 \times 10 \mathrm{~mL})$. The DCM extracts were combined, acidified using $\mathrm{HCl}(2 \mathrm{~mL}, 1 \mathrm{M})$, and extracted with water $(3 \times 10 \mathrm{~mL})$. The aqueous phases were basified using $\mathrm{NaOH}(2 \mathrm{~mL}, 2 \mathrm{M})$ and extracted with DCM $(3 \times 10 \mathrm{~mL})$. The combined organic layers were dried over sodium sulfate, filtered, and evaporated in vacuo to provide $205 \mathrm{mg}$ of crude phenethylamine 6 as a colorless oil which solidified upon standing in a fridge overnight. The hydrochloride salt was precipitated from dry $\mathrm{Et}_{2} \mathrm{O}$ and crystallized from 2-propanol and $\mathrm{Et}_{2} \mathrm{O}$ as a white powder. The final yield of hydrochloride salt was 211 $\operatorname{mg}(87 \%)$.

m.p. ( $\mathrm{HCl}$ salt) $225-227{ }^{\circ} \mathrm{C} ;{ }^{1} \mathbf{H}$ NMR (400 MHz, $\mathrm{CD}_{3} \mathrm{OD}, \mathrm{HCl}$ salt) $\delta 7.21(\mathrm{~s}, 1 \mathrm{H}), 7.12$ $(\mathrm{s}, 1 \mathrm{H}), 3.92(\mathrm{~s}, 3 \mathrm{H}), 3.86(\mathrm{~s}, 3 \mathrm{H}), 3.18(\mathrm{t}, \mathrm{J}=7.3 \mathrm{~Hz}, 2 \mathrm{H}), 3.04(\mathrm{t}, \mathrm{J}=7.4 \mathrm{~Hz}, 2 \mathrm{H}){ }^{13} \mathrm{C} \mathrm{NMR}$ (101 MHz, CD $\mathrm{CD}_{3} \mathrm{HCl}$ salt) $\delta 157.29$ (s), 152.80 (s), 133.89 (s), 117.21 (s), 115.81 (s), 100.99 (s), 57.15 (s), 56.67 (s), 40.23 (s), 30.18 (s).

2,5-Dimethoxy-4-(2-\{[2-(methoxy- $\left.d_{3}\right)$ benzyl]amino\}ethyl)benzonitrile (7)

A freebase phenethylamine $6(103 \mathrm{mg}, 0.5 \mathrm{mmol})$ was dissolved in EtOH $(6 \mathrm{~mL})$, 2-(methoxy- $\left.d_{3}\right)$ benzaldehyde $(77 \mathrm{mg}, 0.55 \mathrm{mmol})$ was added, and the mixture was stirred for $3 \mathrm{~h}$ at room temperature. The mixture was cooled using an ice bath and sodium borohydride ( $76 \mathrm{mg}, 2 \mathrm{mmol}$ ) was added. After stirring for $1 \mathrm{~h}$, water $(1 \mathrm{~mL})$ was added to decompose the remaining sodium borohydride and the solvents were evaporated in vacuo. The residue was dissolved in $10 \mathrm{~mL}$ of water and extracted with DCM $(5 \times 5 \mathrm{~mL})$. The organic phases were combined and the solvent was evaporated in vacuo. The remaining oil was dissolved in $10 \mathrm{~mL}$ of $\mathrm{Et}_{2} \mathrm{O}$ and $\mathrm{HCl}(1 \mathrm{~mL}, 1 \mathrm{M})$ was added. The ethereal layer was extracted with water $(3 \times 10 \mathrm{~mL})$. To the combined water layers $\mathrm{NaOH}(1 \mathrm{~mL}, 2 \mathrm{M})$ was added and extracted using DCM $(5 \times 10 \mathrm{~mL})$. The combined organic phases were dried over sodium sulfate, filtered, and evaporated in vacuo to provide $160 \mathrm{mg}$ of a crude substance 7 as a colorless oil. The hydrochloride salt was precipitated from dry $\mathrm{Et}_{2} \mathrm{O}$ and crystallized twice from $\mathrm{MeOH}$ and $\mathrm{Et}_{2} \mathrm{O}$ as white needles. The final yield of hydrochloride salt was $128 \mathrm{mg}(70 \%)$.

m.p. (HCl salt) $194-196{ }^{\circ} \mathrm{C} ;{ }^{1} \mathbf{H}$ NMR (400 MHz, CD 3 OD) $\delta 7.48-7.43(\mathrm{~m}, 1 \mathrm{H}), 7.43-$ $7.38(\mathrm{~m}, 1 \mathrm{H}), 7.20(\mathrm{~s}, 1 \mathrm{H}), 7.12(\mathrm{~s}, 1 \mathrm{H}), 7.09(\mathrm{~d}, J=8.2 \mathrm{~Hz}, 1 \mathrm{H}), 7.02(\mathrm{tt}, J=4.6,2.3 \mathrm{~Hz}, 1 \mathrm{H})$, $4.26(\mathrm{~s}, 2 \mathrm{H}), 3.91(\mathrm{~s}, 3 \mathrm{H}), 3.82(\mathrm{~s}, 3 \mathrm{H}), 3.28-3.20(\mathrm{~m}, 2 \mathrm{H}), 3.15-3.07(\mathrm{~m}, J=9.4,6.1 \mathrm{~Hz}, 2 \mathrm{H})$; ${ }^{13} \mathrm{C}$ NMR (101 MHz, CD 3 OD) $\delta 159.34$ (s), 157.30 (s), 152.69 (s), 133.64 (s), 132.75 (d, J = 3.2 $\mathrm{Hz}), 122.01$ (s), 120.24 (s), 117.13 (s), 115.87 (s), 115.74 (s), 112.08 (s), 101.09 (s), 57.16 (s), $56.71(\mathrm{~s}), 55.87-54.93(\mathrm{~m}), 47.95(\mathrm{~s}), 47.48(\mathrm{~s}), 28.77(\mathrm{~s})$.

4-\{2-[(4-Hydroxy-2-methoxybenzyl)amino]ethyl\}-2,5-dimethoxybenzonitrile (8)

A freebase phenethylamine $6(102 \mathrm{mg}, 0.5 \mathrm{mmol})$ was added and the mixture was stirred for $3 \mathrm{~h}$ at room temperature. The mixture was cooled using an ice bath and sodium borohydride (76 mg, $2 \mathrm{mmol}$ ) was added. After stirring for $1 \mathrm{~h}$, water $(1 \mathrm{~mL})$ was added to decompose the remaining sodium borohydride and the solvents were evaporated in vacuo. The residue was dissolved in $10 \mathrm{~mL}$ of water and extracted with DCM $(5 \times 5 \mathrm{~mL})$. The organic phases were combined, and the solvent was evaporated in vacuo. The remaining oil was dissolved in $10 \mathrm{~mL}$ of $\mathrm{Et}_{2} \mathrm{O}$ and $\mathrm{HCl}(1 \mathrm{~mL}, 1 \mathrm{M})$ was added. The ethereal layer was extracted with water $(3 \times 10 \mathrm{~mL})$. To the combined water layers, a concentrated solution of ammonia $(1 \mathrm{~mL}, 25 \%)$ was added and the product was extracted using DCM $(5 \times 10 \mathrm{~mL})$. 
The combined organic phases were dried over sodium sulfate, filtered, and evaporated in vacuo to provide $160 \mathrm{mg}$ of a crude substance 8 as a colorless oil. The hydrochloride salt was precipitated from dry $\mathrm{Et}_{2} \mathrm{O}$ and crystallized twice from $\mathrm{MeOH}$ and $\mathrm{Et}_{2} \mathrm{O}$ as white fluffy needles. The final yield of hydrochloride salt was $99 \mathrm{mg}(52 \%)$.

m.p. ( $\mathrm{HCl}$ salt) $208-210{ }^{\circ} \mathrm{C} ;{ }^{1} \mathrm{H}$ NMR $\left(400 \mathrm{MHz}, \mathrm{CD}_{3} \mathrm{OD}, \mathrm{HCl}\right.$ salt $) \delta 7.19(\mathrm{~s}, 1 \mathrm{H}), 7.18$ $(\mathrm{d}, J=8.2 \mathrm{~Hz}, 1 \mathrm{H}), 7.09(\mathrm{~s}, 1 \mathrm{H}), 6.50(\mathrm{~d}, J=2.2 \mathrm{~Hz}, 1 \mathrm{H}), 6.42(\mathrm{dd}, J=8.2,2.2 \mathrm{~Hz}, 1 \mathrm{H}), 4.14$ $(\mathrm{s}, 2 \mathrm{H}), 3.90(\mathrm{~s}, J=9.2 \mathrm{~Hz}, 3 \mathrm{H}), 3.84(\mathrm{~s}, 3 \mathrm{H}), 3.82(\mathrm{~s}, 3 \mathrm{H}), 3.21(\mathrm{dd}, J=9.6,6.1 \mathrm{~Hz}, 2 \mathrm{H}), 3.07$ $(\mathrm{dd}, J=9.4,6.0 \mathrm{~Hz}, 2 \mathrm{H}) ;{ }^{13} \mathrm{C}$ NMR $\left(101 \mathrm{MHz}, \mathrm{CD}_{3} \mathrm{OD}, \mathrm{HCl}\right.$ salt $) \delta 160.58(\mathrm{~s}), 159.13(\mathrm{~s})$, $155.85(\mathrm{~s}), 151.24(\mathrm{~s}), 132.22(\mathrm{~s}), 115.65(\mathrm{~s}), 114.39(\mathrm{~s}), 114.24(\mathrm{~s}), 109.32(\mathrm{~s}), 107.00(\mathrm{~s}), 99.62(\mathrm{~s})$, $98.52(\mathrm{~s}), 55.69(\mathrm{~s}), 55.25(\mathrm{~s}), 54.61(\mathrm{~s}), 46.22(\mathrm{~s}), 45.60(\mathrm{~s}), 27.33(\mathrm{~s})$.

4-\{2-[(2-Hydroxybenzyl)amino]ethyl\}-2,5-dimethoxybenzonitrile (9)

Substance 9 was prepared from the phenethylamine $6(103 \mathrm{mg}, 0.5 \mathrm{mmol})$ and salicylaldehyde $(67 \mathrm{mg}, 0.55 \mathrm{mmol})$ in the same way as substance 8 . The crude substance 9 (105 mg) was isolated as a colorless oil. The hydrochloride salt was precipitated from dry $\mathrm{Et}_{2} \mathrm{O}$ and crystallized twice from $\mathrm{MeOH}$ and $\mathrm{Et}_{2} \mathrm{O}$ as white needles. The final yield of hydrochloride salt was $75 \mathrm{mg}(44 \%)$.

m.p. (HCl salt) $198-201{ }^{\circ} \mathrm{C} ;{ }^{1} \mathbf{H}$ NMR $\left(400 \mathrm{MHz}, \mathrm{CD}_{3} \mathrm{OD}, \mathrm{HCl}\right.$ salt) $\delta 7.35-7.26(\mathrm{~m}, 2 \mathrm{H})$, $7.20(\mathrm{~s}, 1 \mathrm{H}), 7.11(\mathrm{~s}, 1 \mathrm{H}), 6.94-6.87(\mathrm{~m}, 2 \mathrm{H}), 4.24(\mathrm{~d}, \mathrm{~J}=6.5 \mathrm{~Hz}, 2 \mathrm{H}), 3.91(\mathrm{~s}, 3 \mathrm{H}), 3.83(\mathrm{~s}, 3 \mathrm{H})$, $3.26(\mathrm{dd}, \mathrm{J}=8.9,6.4 \mathrm{~Hz}, 2 \mathrm{H}), 3.11(\mathrm{dd}, \mathrm{J}=8.8,6.5 \mathrm{~Hz}, 2 \mathrm{H}) ;{ }^{13} \mathrm{C} \mathrm{NMR}\left(101 \mathrm{MHz}, \mathrm{CD}_{3} \mathrm{OD}, \mathrm{HCl}\right.$ salt) $\delta 157.47(\mathrm{~s}), 157.31(\mathrm{~s}), 152.67(\mathrm{~s}), 133.70(\mathrm{~s}), 132.63(\mathrm{~s}), 132.37(\mathrm{~s}), 121.01(\mathrm{~s}), 118.64(\mathrm{~s})$, 117.16 (s), $116.25(\mathrm{~s}), 115.84(\mathrm{~s}), 115.75(\mathrm{~s}), 101.07$ (s), $57.14(\mathrm{~s}), 56.68$ (s), 48.21 (s), 47.39 (s), $28.81(\mathrm{~s})$.

4-[2-(1,3-Dioxoisoindolin-2-yl)ethyl]-2-hydroxy-5-methoxybenzonitrile (10)

Phthalimide 5 ( $335 \mathrm{mg}, 1 \mathrm{mmol})$ was dissolved in dry DCM $(15 \mathrm{~mL})$ under an inert atmosphere. The solution was cooled to $-79{ }^{\circ} \mathrm{C}$ and $\mathrm{BBr}_{3}$ in $\mathrm{DCM}(1.3 \mathrm{~mL}, 1 \mathrm{M})$ was added dropwise during $5 \mathrm{~min}$. The mixture was allowed to gradually warm back to room temperature for $3 \mathrm{~h}$ and then stirred for $48 \mathrm{~h}$. Then, the reaction was cooled using an ice bath, quenched with EtOH $(2 \mathrm{~mL})$, and diluted with DCM $(30 \mathrm{~mL})$. Saturated $\mathrm{NaHCO}_{3}$ solution $(20 \mathrm{~mL})$ was added to neutralize the $\mathrm{HBr}$, layers were separated, and the water phase was extracted with DCM $(2 \times 20 \mathrm{~mL})$. The combined organic phases were washed with $\mathrm{NaHCO}_{3}(20 \mathrm{~mL})$, dried over sodium sulfate, filtered, and evaporated in vacuo. The residue was purified using flash chromatography on an in-house made column filled with polar silica (DCM-EtOAc, gradual elution). It was recovered $126 \mathrm{mg}(37 \%)$ of starting substance 5. Product 10 was further recrystallized from the 2-propanol-DCM mixture yielding $107 \mathrm{mg}(33 \%)$.

m.p. $248-251{ }^{\circ} \mathrm{C} ;{ }^{1} \mathbf{H}$ NMR $(600 \mathrm{MHz}, \mathrm{DMSO}) \delta 10.39(\mathrm{~s}, 1 \mathrm{H}), 7.87-7.80(\mathrm{~m}, 4 \mathrm{H}), 7.05$ $(\mathrm{s}, 1 \mathrm{H}), 6.75(\mathrm{~s}, 1 \mathrm{H}), 3.79(\mathrm{t}, J=6.6 \mathrm{~Hz}, 2 \mathrm{H}), 3.54(\mathrm{~s}, 3 \mathrm{H}), 2.87(\mathrm{t}, J=6.6 \mathrm{~Hz}, 2 \mathrm{H}) ;{ }^{13} \mathrm{C}$ NMR (151 MHz, DMSO) $\delta 168.05$ (s), 154.56 (s), 150.63 (s), 134.74 (s), 132.09 (s), 123.46 (s), 118.65 (s), $117.39(\mathrm{~s}), 113.86(\mathrm{~s}), 96.87(\mathrm{~s}), 56.43(\mathrm{~s}), 37.76(\mathrm{~s}), 29.53(\mathrm{~s})$.

4-(2-Aminoethyl)-2-hydroxy-5-methoxybenzonitrile (11)

Phthalimide 10 (101 mg, $0.31 \mathrm{mmol})$ was suspended in 2-propanol $(12 \mathrm{~mL})$ and water ( $2 \mathrm{~mL}$ ). The mixture was cooled to $0{ }^{\circ} \mathrm{C}$ and sodium borohydride $(117 \mathrm{mg}, 3.1 \mathrm{mmol})$ was added portion-wise for $5 \mathrm{~min}$. The mixture was flushed with argon and stirred at room temperature overnight. The next day glacial acetic acid $(2 \mathrm{~mL})$ was added dropwise for $5 \mathrm{~min}$ and the solution was refluxed for $5 \mathrm{~h}$. After cooling to room temperature, $\mathrm{HCl}$ $(0.35 \mathrm{~mL}, 35 \%)$ was added and the solvent evaporated. Usually, an acid-base extraction would be used for workup. However, this method couldn't be used due to the high solubility of $\mathbf{1 1}$ in water. Instead, the remaining boric acid was removed as trimethyl borate. $\mathrm{MeOH}(20 \mathrm{~mL})$ was added and the solvent evaporated. This procedure was repeated two more times. The residue was dissolved in $\mathrm{EtOH}$, and undissolved sodium chloride was filtered off. The EtOH solution was evaporated in vacuo and the residue was dissolved in $10 \mathrm{~mL}$ of distilled water. The mixture was washed with DCM $(3 \times 5 \mathrm{~mL})$ and the water portion was evaporated, leaving behind $65 \mathrm{mg}(92 \%)$ of a hydrochloride salt of phenethylamine $\mathbf{1 1}$ as a yellow powder. 
m.p. ( $\mathrm{HCl}$ salt) $215-219{ }^{\circ} \mathrm{C} ;{ }^{\mathbf{1}} \mathbf{H}$ NMR (400 MHz, $\mathrm{CD}_{3} \mathrm{OD}, \mathrm{HCl}$ salt) $\delta 7.08$ (s, $\left.1 \mathrm{H}\right)$, $6.88(\mathrm{~d}, \mathrm{~J}=3.6 \mathrm{~Hz}, 1 \mathrm{H}), 3.83(\mathrm{~d}, \mathrm{~J}=2.9 \mathrm{~Hz}, 3 \mathrm{H}), 3.21-3.08(\mathrm{~m}, 2 \mathrm{H}), 3.01-2.90(\mathrm{~m}, 2 \mathrm{H}) ;{ }^{13} \mathrm{C}$ NMR (101 MHz, CD 3 OD, HCl salt) $\delta 155.94$ (s), 152.00 (s), 134.03 (s), 119.61 (s), 117.72 (s), 114.78 (s), 99.17 (s), 56.55 (s), 40.26 (s), 30.04 (s).

2-Hydroxy-4-\{2-[(2-hydroxybenzyl)amino]ethyl\}-5-methoxybenzonitrile (12)

The hydrochloride salt of phenethylamine 11 (46 mg, $0.2 \mathrm{mmol})$, salicylaldehyde ( $37 \mathrm{mg}, 0.3 \mathrm{mmol}$ ), and triethylamine ( $40 \mathrm{mg}, 0.4 \mathrm{mmol})$ were dissolved in EtOH (2 mL) and the mixture was stirred under an inert atmosphere overnight. The mixture was cooled to $0{ }^{\circ} \mathrm{C}$, sodium borohydride $(38 \mathrm{mg}, 1 \mathrm{mmol}$ ) was added and the stirring was continued for $1 \mathrm{~h}$. The solvent was evaporated and $\mathrm{MeOH}(10 \mathrm{~mL})$ and $\mathrm{HCl}(0.15 \mathrm{~mL}, 35 \%)$ were added. The boric acid was evaporated in vacuo as trimethyl borate. Further $10 \mathrm{~mL}$ of $\mathrm{MeOH}$ were added, and the process was repeated 2 more times to get rid of all the boric acid. The residue was dissolved in $\mathrm{EtOH}$ and undissolved sodium chloride was filtered off. The EtOH solution was evaporated in vacuo and the residue was dissolved in $10 \mathrm{~mL}$ of distilled water. The mixture was washed with DCM $(3 \times 5 \mathrm{~mL})$ and the water portion was stirred with activated charcoal for $2 \mathrm{~h}$. After filtering off the charcoal, the water was evaporated, leaving behind the hydrochloride salt of substance $\mathbf{1 2}$ as a light gray powder. The final yield of the hydrochloride salt was $31 \mathrm{mg}(46 \%)$. The substance has darkened upon standing at room temperature for few days. Therefore, it is recommended to store it under an inert atmosphere in a fridge.

m.p. ( $\mathrm{HCl}$ salt) $72-76{ }^{\circ} \mathrm{C}$ (decompose); ${ }^{1} \mathrm{H}$ NMR (300 MHz, $\mathrm{CD}_{3} \mathrm{OD}, \mathrm{HCl}$ salt) $\delta$ 7.35-7.23 (m, $J=13.8,7.3 \mathrm{~Hz}, 2 \mathrm{H}), 7.06(\mathrm{~s}, 1 \mathrm{H}), 6.95-6.84(\mathrm{~m}, 3 \mathrm{H}), 4.21(\mathrm{~s}, 2 \mathrm{H}), 3.79(\mathrm{~s}, 3 \mathrm{H})$, 3.26-3.16 (m, 2H), 3.08-2.94 (m, 2H); ${ }^{13} \mathrm{C}$ NMR (101 MHz, CD $\mathrm{CD}_{3} \mathrm{HCl}$ salt) $\delta 156.04$ (s), 154.56 (s), 150.45 (s), 132.43 (s), 131.18 (s), 130.94 (s), 119.59 (s), 118.16 (s), 117.19 (s), 116.23 (s), 114.83 (s), 113.40 (s), 97.83 (s), 55.14 (s), 46.79 (s), 46.01 (s), 27.26 (s).

2-Hydroxy-5-methoxy-4-\{2-[(2-methoxybenzyl)amino]ethyl\}benzonitrile (13)

The substance 13 was prepared from the hydrochloride of phenethylamine $\mathbf{1 1}$ (38 mg, $0.17 \mathrm{mmol}$ ) and 2-methoxybenzaldehyde (23 $\mathrm{mg}, 0.25 \mathrm{mmol})$ in the same way as the substance 12. The crude hydrochloride salt of substance $\mathbf{1 3}$ was further purified using chromatography on reverse phase silica pre-packed in RediSep ${ }^{\circledR}$ Gold C18 column (MeOHwater, gradual elution). The final yield of the hydrochloride salt was $8 \mathrm{mg}(14 \%)$.

m.p. ( $\mathrm{HCl}$ salt) $193-196{ }^{\circ} \mathrm{C}$; ${ }^{1} \mathbf{H}$ NMR (400 MHz, CD $\mathrm{CD}_{3} \mathrm{OCl}$ salt) $\delta$ 7.49-7.41 (m, $1 \mathrm{H}), 7.38(\mathrm{dd}, J=7.5,1.5 \mathrm{~Hz}, 1 \mathrm{H}), 7.13-6.95(\mathrm{~m}, 3 \mathrm{H}), 6.85(\mathrm{~s}, 1 \mathrm{H}), 4.24(\mathrm{~s}, 2 \mathrm{H}), 3.91(\mathrm{~s}, 3 \mathrm{H})$, $3.80(\mathrm{~s}, 3 \mathrm{H}), 3.21(\mathrm{dd}, J=9.2,6.3 \mathrm{~Hz}, 2 \mathrm{H}), 3.01(\mathrm{dd}, J=9.1,6.4 \mathrm{~Hz}, 2 \mathrm{H}) ;{ }^{13} \mathrm{C} \mathrm{NMR}(101 \mathrm{MHz}$, $\mathrm{CD}_{3} \mathrm{OD}, \mathrm{HCl}$ salt) $\delta 157.91$ (s), 154.62 (s), 150.45 (s), 132.36 (s), 131.30 (s), 131.23 (s), 120.63 (s), 118.96 (s), 118.15 (s), 116.20 (s), 113.44 (s), 110.66 (s), 97.88 (s), 55.14 (s), 54.74 (s), 46.56 (s), $46.10(\mathrm{~s}), 27.28(\mathrm{~s})$.

\subsection{Sample Preparation}

\subsubsection{Human Liver Microsomes}

Internal standard $\left(20 \mu \mathrm{L}\right.$ of $1 \mu \mathrm{g} \cdot \mathrm{mL}^{-1}$ solution of $\left.25 \mathrm{CN}-\mathrm{NBOMe}-\mathrm{d}_{3}\right)$ was added to each liquid sample $(200 \mu \mathrm{L})$. Samples were concentrated by evaporation of acetonitrile using speedvac (Hanil Modul 4080C) and ammonium bicarbonate solution was used to adjust their $\mathrm{pH}$ to 8.4 approximately. The resulting aqueous phase was extracted with $400 \mu \mathrm{L}$ of ether twice, and combined organic extracts were evaporated to dryness. The dry residue was reconstituted in $200 \mu \mathrm{L}$ of $5 \%(v / v)$ methanol in $0.1 \%$ formic acid and this solution was transferred to an HPLC vial.

\subsubsection{C. elegans Mycelium \& Culture Medium}

Internal standard $\left(20 \mu \mathrm{L}\right.$ of $1 \mu \mathrm{g} \cdot \mathrm{mL}^{-1}$ solution of $\left.25 \mathrm{CN}-\mathrm{NBOMe}-\mathrm{d}_{3}\right)$ was added to each media sample $(200 \mu \mathrm{L})$ and ammonium bicarbonate solution was used to adjust the sample's pH to 8.4 approximately. The resulting aqueous phase was extracted with $400 \mu \mathrm{L}$ of ether twice, and combined organic extracts were evaporated to dryness. The dry residue 
was reconstituted in $200 \mu \mathrm{L}$ of $5 \%(v / v)$ methanol in $0.1 \%$ formic acid and this solution was transferred into an HPLC vial.

C. elegans mycelium was thawed and cut into small pieces. Approximately $300 \mathrm{mg}$ of wet material, $100 \mathrm{mg}$ of bullets for homogenization (Next Advance ZrOB05-yttriastabilized zirconium oxide beads, $0.5 \mathrm{~mm}$ dia.), and $1 \mathrm{~mL}$ of $0.1 \%$ formic acid were added to the weighted Eppendorf tube. Each sample was thoroughly vortexed and homogenized using the Bullet Blender Gold (Next Advance) at $4{ }^{\circ} \mathrm{C}(10 \mathrm{~min}$, speed 8$)$. Consequently, the samples were centrifuged for $10 \mathrm{~min}$ at $13,200 \mathrm{RPM}$ at $4{ }^{\circ} \mathrm{C}$ (Eppendorf Centrifuge $5415 \mathrm{R}$ ), the resulting supernatants were separated and their $\mathrm{pH}$ was adjusted to 8.4 approximately by addition of ammonium bicarbonate solution. The aqueous phase was extracted with $400 \mu \mathrm{L}$ of ether three times and combined organic extracts were evaporated to dryness. The dry residue was reconstituted in $300 \mu \mathrm{L}$ of $5 \%(v / v)$ methanol in $0.1 \%$ formic acid and this solution was transferred to an HPLC vial.

\subsubsection{Rat Urine}

A method for metabolomics studies of NPS in rat urine was adapted [51]. Collected urine samples $(200 \mu \mathrm{L})$ were diluted with the same volume of $9 \%(v / v)$ methanol in $0.1 \%$ formic acid containing internal standard $\left(200 \mathrm{ng} \cdot \mathrm{mL}^{-1}\right.$ of $\left.25 \mathrm{CN}-\mathrm{NBOMe}-\mathrm{d}_{3}\right)$ and thoroughly vortexed. Consequently, the samples were centrifuged for 10 min at 13,200 RPM at $4{ }^{\circ} \mathrm{C}$ (Eppendorf Centrifuge $5415 \mathrm{R}$ ). The resulting supernatants were transferred to HPLC vials.

\subsection{LC-MS Analysis \\ 3.6.1. Untargeted Screening}

An UltiMate 3000 LC system (Thermo, Waltham, MA, USA) coupled with a hybrid quadrupole time-of-flight TripleTOF 5600 mass spectrometer (AB Sciex, Framingham, MA, USA) equipped with an ESI ion source was used for information-dependent acquisition (IDA) analyses. Prepared samples were separated with a Kinetex C18 $(3 \times 50 \mathrm{~mm}$, $2.6 \mu \mathrm{m}$ ) LC column (Phenomenex, Torrance, CA, USA). A gradient elution with $0.1 \%$ formic acid $+5 \mathrm{mM}$ ammonium formate in water (mobile phase $\mathrm{A}$ ) and $0.1 \%$ formic acid in methanol (mobile phase B) was applied with the following time profile: $0 \mathrm{~min}, 98: 2$ (A:B); $0.3 \mathrm{~min}, 98: 2 ; 0.4 \mathrm{~min}, 96: 4 ; 1 \mathrm{~min}, 90: 10 ; 12 \mathrm{~min}, 0: 100 ; 16 \mathrm{~min}, 0: 100 ; 17.6 \mathrm{~min}, 90: 10$; $18 \mathrm{~min}, 98: 2 ; 20 \mathrm{~min}, 98: 2$. The flow rate of the mobile phase was $200 \mu \mathrm{L} \cdot \mathrm{min}^{-1}$ and column temperature was set at $30^{\circ} \mathrm{C}$.

The MS/MS apparatus was operating in high sensitivity positive mode. The applied parameters of electrospray ion source were: temperature $350^{\circ} \mathrm{C}$, curtain gas (CUR) 35 psi, nebulizer gas (GS1) 30 psi and heater gas (GS2) 40 psi; ion spray voltage floating (ISVF) was set to $4000 \mathrm{~V}$. The data acquisition mode in the information-dependent acquisition (IDA) experiments was set to obtain a high-resolution TOF-MS and MS/MS scans, both over a mass range $50-800 \mathrm{~m} / \mathrm{z}$. Collision-induced dissociation was triggered by rolling collision energy. Raw data generated from IDA were evaluated using Sciex OS-Q version 1.5.0.23389 software.

\subsubsection{Human Liver Microsomes and C. elegans Samples}

The analysis was performed using the UltiMate 3000 LC system (Thermo) coupled with the QTrap 6500 mass spectrometer (AB Sciex) equipped with a Turbo V ESI ion source. Prepared samples (injection volume $10 \mu \mathrm{L}$ ) were separated with a Luna Omega Polar C18 $(2.1 \times 100 \mathrm{~mm}, 3 \mu \mathrm{m})$ column (Phenomenex). A gradient elution with $0.1 \%$ formic acid $+5 \mathrm{mM}$ ammonium formate in water (mobile phase A) and methanol (mobile phase B) was applied with the following time profile: $0 \mathrm{~min}, 98: 2$ (A:B); $2 \mathrm{~min}, 98: 2 ; 12 \mathrm{~min}$, 2:98; $14.5 \mathrm{~min}, 2: 98 ; 15 \mathrm{~min}, 98: 2 ; 20 \mathrm{~min}, 98: 2$. The flow rate of the mobile phase was $400 \mu \mathrm{L} \cdot \min ^{-1}$ and the column temperature was set at $30{ }^{\circ} \mathrm{C}$.

The MS/MS apparatus was operating in positive mode. The applied parameters of electrospray ion source were: temperature $450{ }^{\circ} \mathrm{C}$, curtain gas (CUR) 20 psi, nebulizer gas 
(GS1) 30 psi and heater gas (GS2) 30 psi; ion spray voltage was set to $5350 \mathrm{~V}$. A scan-free $\mathrm{MS}^{3}$ (MS/MS/MS) method [44] was developed for screening of 25CN-NBOMe metabolites, the details are summarized in Table 3. For data acquisition and management, Analyst software version 1.63 and MultiQuant 3.0.3 were utilized (AB Sciex).

Table 3. Parameters of the developed scan-free $\mathrm{MS}^{3}$ quantification method-observed transitions and appropriate ion source parameters for individual metabolites.

\begin{tabular}{|c|c|c|c|c|c|}
\hline & $\begin{array}{c}\text { 1st Precursor } \\
{[\mathrm{m} / \mathrm{z}]}\end{array}$ & $\begin{array}{c}\text { 2nd Precursor } \\
{[\mathrm{m} / \mathrm{z}]}\end{array}$ & $\begin{array}{c}\text { Quantifier/Qualifier } \\
\text { Ion }[m / z]\end{array}$ & $\begin{array}{l}\mathrm{CE}^{1} \\
{[\mathrm{eV}]}\end{array}$ & $\begin{array}{c}\mathrm{DP}^{2} \\
{[\mathrm{~V}]}\end{array}$ \\
\hline \multirow{2}{*}{ 25CN-NBOMe } & 327.2 & 121.1 & 93.0 & 19 & 9 \\
\hline & 327.2 & 205.1 & 190.1 & 15 & 42 \\
\hline \multirow{2}{*}{ O-demethyl-25CN-NBOMe (13) } & 313.2 & 121.1 & 93.0 & 21 & 30 \\
\hline & 313.2 & 91.0 & 65.0 & 64 & 21 \\
\hline \multirow{2}{*}{ 25CN-NBOH (9) } & 313.2 & 207.2 & 190.1 & 17 & 90 \\
\hline & 313.2 & 190.1 & 175.1 & 21 & 17 \\
\hline \multirow{2}{*}{ O-demethyl-25CN-NBOH (12) } & 299.2 & 176.1 & 161.1 & 22 & 65 \\
\hline & 299.2 & 193.1 & 176.1 & 17 & 60 \\
\hline \multirow{2}{*}{$2 \mathrm{C}-\mathrm{CN}(6)$} & 207.2 & 175.1 & 160.1 & 26 & 50 \\
\hline & 207.2 & 190.1 & 175.1 & 14 & 30 \\
\hline \multirow{2}{*}{ O-demethyl-2C-CN (11) } & 193.1 & 176.1 & 161.1 & 15 & 15 \\
\hline & 193.1 & 161.1 & 132.1 & 28 & 39 \\
\hline \multirow{2}{*}{ hydroxy-25CN-NBOMe (8) } & 343.3 & 207.2 & 190.1 & 12 & 36 \\
\hline & 343.3 & 190.1 & 175.1 & 17 & 21 \\
\hline \multirow{2}{*}{$25 \mathrm{CN}-\mathrm{NBOMe}-\mathrm{d}_{3}(7)$} & 330.2 & 124.1 & 96.0 & 24 & 22 \\
\hline & 330.2 & 205.1 & 190.1 & 15 & 42 \\
\hline
\end{tabular}

${ }^{1} \mathrm{CE}=$ collision energy; ${ }^{2} \mathrm{DP}=$ declustering potential.

\subsubsection{Rat urine Samples}

The analysis was performed using the MicroLC 200 Plus microflow LC system (Eksigent) coupled with the QTrap 6500+ mass spectrometer (AB Sciex) equipped with an Optiflow Micro ESI ion source. Prepared samples (injection volume $20 \mu \mathrm{L}$ ) were separated by a YMC-Triart C18 $(0.3 \times 150 \mathrm{~mm}, 3 \mu \mathrm{m})$ column (YMC) protected with a KrudKatcher UHPLC in-line filter. Gradient elution with $0.1 \%$ formic acid in water (mobile phase A) and methanol (mobile phase B) was applied with the following time profile: 0 min, 95:5 (A:B); $1 \mathrm{~min}, 95: 5 ; 2.5 \mathrm{~min}, 5: 95 ; 6 \mathrm{~min}, 5: 95 ; 7 \mathrm{~min}, 95: 5 ; 15 \mathrm{~min}, 95: 5$. The flow rate of the mobile phase was $7 \mu \mathrm{L} \cdot \min ^{-1}$ and column temperature was set at $22{ }^{\circ} \mathrm{C}$.

The MS/MS apparatus was operating in positive mode. The applied parameters of electrospray ion source were: temperature $200{ }^{\circ} \mathrm{C}$, curtain gas (CUR) 20 psi, nebulizer gas (GS1) 20 psi and heater gas (GS2) 20 psi; ion spray voltage was set to 5000 V. For screening of $25 \mathrm{CN}-\mathrm{NBOMe}$ metabolites in urine samples, the previously described scanfree $\mathrm{MS}^{3}$ experiment was used, its experimental details are summarized in Table 1. For data acquisition and management, Analyst software version 1.7.1 and MultiQuant 3.0.3 were utilized (AB Sciex).

\section{Conclusions}

Our 25CN-NBOMe metabolism study in rat urine, human liver microsomes, and mycelium of $C$. elegans confirmed that it is metabolized through $O$-demethylation, hydroxylation, and $N$-demethoxybenzylation as the major pathways, analogously to published in vitro and in vivo studies on 25B-, 25C-, and 25I-NBOMe. However, a difference in the position of hydroxylation was detected. We also identified the fate of the nitrile group, which was hydrolyzed and/or oxidized to amid or carboxylic acid by mycelium and rats, respectively, but remained unchanged in the human liver microsomes. The most abundant metabolites may serve as biomarkers of the $25 \mathrm{CN}-\mathrm{NBOMe}$ intoxication. 
Supplementary Materials: The following are available online at https://www.mdpi.com/article/10 $.3390 /$ metabo11040212/s1, Table S1. List of 25CN-NBOMe phase I and phase II metabolites with recorded precursor ion exact mass (TOF-MS), the corresponding characteristic fragment ions with the calculated exact masses (HR-MS/MS), elemental compositions, and deviations of the measured from the calculated masses.

Author Contributions: Conceptualization, A.Š., J.N. and M.K.; methodology, A.Š., J.N., T.L. and S.R.; formal analysis, A.Š.; resources, A.Š., J.N., P.P and K.Š.; data curation, A.Š. and J.N.; writing-original draft preparation, A.Š., P.P. and J.N.; writing-review and editing, S.R., T.P. and M.K.; supervision, M.K. and R.J.; project administration, M.K. and T.P.; funding acquisition, M.K. All authors have read and agreed to the published version of the manuscript.

Funding: This research was funded by the Ministry of the Interior of the Czech Republic, grant number MV0/VI20172020056.

Institutional Review Board Statement: The study was approved by the National Committee for the Care and Use of Laboratory Animals (Prague, Czech Republic), and Guidelines of the European Union (86/609/EU). The protocol was approved by the National Committee for the Care and Use of Laboratory Animals (Prague, Czech Republic) under the number: 59449/2016-MZE-17214.

Informed Consent Statement: Not applicable.

Data Availability Statement: The source data available upon a reasonable request.

Acknowledgments: The authors would like to acknowledge Jakub Rak and David Kačer (National institute of mental health) for providing the technical support for LCMS data analysis for this study.

Conflicts of Interest: The authors declare no conflict of interest.

\section{References}

1. Glennon, R.A.; Dukat, M.; El-Bermawy, M.; Law, H.; Angeles, J.D.L.; Teitler, M.; King, A.; Herrick-Davis, K. Influence of amine substituents on 5-HT2A versus 5-HT2C binding of phenylalkyl- and indolylalkylamines. J. Med. Chem. 1994, 37, 1929-1935. [CrossRef]

2. $\quad$ Ettrup, A.; Hansen, M.; Santini, M.A.; Paine, J.; Gillings, N.; Palner, M.; Lehel, S.; Herth, M.M.; Madsen, J.; Kristensen, J.; et al. Radiosynthesis and in vivo evaluation of a series of substituted $11 \mathrm{C}$-phenethylamines as 5-HT 2A agonist PET tracers. Eur. J. Nucl. Med. Mol. Imaging 2011, 38, 681-693. [CrossRef]

3. Ettrup, A.; Da Cunha-Bang, S.; McMahon, B.; Lehel, S.; Dyssegaard, A.; Skibsted, A.W.; Jørgensen, L.M.; Hansen, M.; O Baandrup, A.; Bache, S.; et al. Serotonin 2A Receptor Agonist Binding in the Human Brain with [11C]Cimbi-36. Br. J. Pharmacol. 2014, 34, 1188-1196. [CrossRef] [PubMed]

4. Hansen, M. Design and Synthesis of Selective Serotonin Receptor Agonists for Positron Emission Tomography Imaging of the Brain. Ph.D. Thesis, University of Copenhagen, Copenhagen, Switzerland, 2010.

5. Hansen, M.; Phonekeo, K.; Paine, J.S.; Leth-Petersen, S.; Begtrup, M. Synthesis and structure-activity relationships of N-Benzyl phenethylamines as 5-HT2A/2C agonists. ACS Chem. Neurosci. 2014, 5, 243-249. [CrossRef]

6. Jensen, A.A.; McCorvy, J.D.; Leth-Petersen, S.; Bundgaard, C.; Liebscher, G.; Kenakin, T.P.; Bräuner-Osborne, H.; Kehler, J.; Kristensen, J.L. Detailed characterization of the in vitro pharmacological and pharmacokinetic properties of N-(2-hydroxybenzyl)2, 5-dimethoxy-4-cyanophenylethylamine (25CN-NBOH), a highly selective and brain-penetrant 5-HT2A receptor agonist. J. Pharmacol. Exp. Ther. 2017, 361, 441-453. [CrossRef] [PubMed]

7. Zuba, D.; Sekuła, K.; Buczek, A. 25C-NBOMe-New potent hallucinogenic substance identified on the drug market. Forensic Sci. Int. 2013, 227, 7-14. [CrossRef] [PubMed]

8. Poklis, J.L.; Raso, S.A.; Alford, K.N.; Poklis, A.; Peace, M.R. Analysis of 25I-NBOMe, 25B-NBOMe, 25C-NBOMe and other dimethoxyphenyl-N-[(2-Methoxyphenyl)Methyl] ethanamine derivatives on blotter paper. J. Anal. Toxicol. 2015, 39, 617-623. [CrossRef] [PubMed]

9. Halberstadt, A.L. Pharmacology and toxicology of N-benzylphenethylamine ("NBOMe") hallucinogens. Curr. Top. Behav. Neurosci. 2017, 32, 283-311. [CrossRef] [PubMed]

10. Glennon, R.A.; Titeler, M.; McKenney, J.D. Evidence for 5-HT2 involvement in the mechanism of action of hallucinogenic agents. Life Sci. 1984, 35, 2505-2511. [CrossRef]

11. Titeler, M.; Lyon, R.A.; Glennon, R.A. Radioligand binding evidence implicates the brain 5-HT2 receptor as a site of action for LSD and phenylisopropylamine hallucinogens. Psychopharmacology 1988, 94, 213-216. [CrossRef] [PubMed]

12. Vollenweider, F.X.; Vollenweider-Scherpenhuyzen, M.F.I.; Bäbler, A.; Vogel, H.; Hell, D. Psilocybin induces schizophrenia-like psychosis in humans via a serotonin-2 agonist action. Neuroreport 1998, 9, 3897-3902. [CrossRef] [PubMed]

13. Quednow, B.B.; Kometer, M.; Geyer, M.A.; Vollenweider, F.X. Psilocybin-induced deficits in automatic and controlled inhibition are attenuated by ketanserin in healthy human volunteers. Neuropsychopharmacology 2012, 37, 630-640. [CrossRef] [PubMed] 
14. Valle, M.; Maqueda, A.E.; Rabella, M.; Rodríguez-Pujadas, A.; Antonijoan, R.M.; Romero, S.; Alonso, J.F.; Mañanas, M.À.; Barker, S.; Friedlander, P.; et al. Inhibition of alpha oscillations through serotonin-2A receptor activation underlies the visual effects of ayahuasca in humans. Eur. Neuropsychopharmacol. 2016, 26, 1161-1175. [CrossRef] [PubMed]

15. Halberstadt, A.L. Recent advances in the neuropsychopharmacology of serotonergic hallucinogens. Behav. Brain Res. 2014, 277, 99-120. [CrossRef] [PubMed]

16. Pertz, H.H.; Heim, R.; Elz, S. N-Benzylated phenylethanamines are highly potent partial agonists at 5-HT2A receptors (abstract). Arch. Pharm. Pharm. Med. Chem. 2000, 333, 30.

17. Braden, M.R.; Parrish, J.C.; Naylor, J.C.; Nichols, D.E. Molecular interaction of serotonin 5-HT 2A receptor residues phenethylamine agonists. Mol. Pharmacol. 2006, 70, 1956-1964. [CrossRef] [PubMed]

18. Eshleman, A.J.; Wolfrum, K.M.; Reed, J.F.; Kim, S.O.; Johnson, R.A.; Janowsky, A. Neurochemical pharmacology of psychoactive substituted N-benzylphenethylamines: High potency agonists at 5-HT2A receptors. Biochem Pharmacol. 2018, 158, 27-34. [CrossRef] [PubMed]

19. Heim, R. Synthese und Pharmakologie Potenter 5-HT2A-Rezeptoragonisten mit N-2-Methoxybenzyl-Partialstruktur. Ph.D. Thesis, Fachbereich Biologie, Chemie Pharmazie der Freien Universität, Berlin, Germany, 25 March 2003.

20. Elmore, J.S.; Decker, A.M.; Sulima, A.; Rice, K.C.; Partilla, J.S.; Blough, B.E.; Baumann, M.H.; Carolina, N.; Section, S. Comparative neuropharmacology of N-(2-methoxybenzyl)-2,5-dimethoxyphenethylamine (NBOMe) hallucinogens and their 2C counterparts in male rats. Neuropharmacology 2019, 142, 240-250. [CrossRef]

21. Rickli, A.; Luethi, D.; Reinisch, J.; Buchy, D.; Hoener, M.C.; Liechti, M.E. Receptor interaction profiles of novel N-2-methoxybenzyl (NBOMe) derivatives of 2,5-dimethoxy-substituted phenethylamines (2C drugs). Neuropharmacology 2015, 99, 546-553. [CrossRef]

22. Halberstadt, A.L.; Geyer, M.A. Characterization of the head-twitch response induced by hallucinogens in mice. Detection of the behavior based on the dynamics of head movement. Psychopharmacology 2013, 227, 727-739. [CrossRef]

23. Canal, C.E.; Morgan, D. Head-twitch response in rodents induced by the hallucinogen 2,5-dimethoxy-4-iodoamphetamine: A comprehensive history, a re-evaluation of mechanisms, and its utility as a model. Drug Test. Anal. 2012, 4, 556-576. [CrossRef] [PubMed]

24. Halberstadt, A.L.; Chatha, M.; Klein, A.K.; Wallach, J.; Brandt, S.D. Correlation between the potency of hallucinogens in the mouse head-twitch response assay and their behavioral and subjective effects in other species. Neuropharmacology 2020, 167, 107933. [CrossRef] [PubMed]

25. Ettrup, A.; Holm, S.; Hansen, M.; Wasim, M.; Santini, M.A.; Palner, M.; Madsen, J.; Svarer, C.; Kristensen, J.L.; Knudsen, G.M. Preclinical safety assessment of the 5-HT2A receptor agonist PET radioligand $\left[{ }^{11} \mathrm{C}\right]$ Cimbi-36. Mol. Imaging Biol. 2013, 15, 376-383. [CrossRef] [PubMed]

26. Halberstadt, A.L.; Geyer, M.A. Effects of the hallucinogen 2,5-dimethoxy-4-iodophenethylamine (2C-I) and superpotent N-benzyl derivatives on the head twitch response. Neuropharmacology 2014, 77, 200-207. [CrossRef] [PubMed]

27. Suzuki, J.; Poklis, J.L.; Poklis, A. "My friend said it was good LSD": A suicide attempt following analytically confirmed 25I-NBOMe ingestion. J. Psychoact. Drugs 2014, 46, 37-41. [CrossRef] [PubMed]

28. Poklis, J.L.; Devers, K.G.; Arbefeville, E.F.; Pearson, J.M.; Houston, E.; Poklis, A. Postmortem detection of 25I-NBOMe [2-(4iodo-2,5-dimethoxyphenyl)-N-[(2-methoxyphenyl)methyl]ethanamine] in fluids and tissues determined by high performance liquid chromatography with tandem mass spectrometry from a traumatic death. Forensic Sci. Int. 2013, 234, e14-e20. [CrossRef] [PubMed]

29. Poklis, J.L.; Dempsey, S.K.; Liu, K.; Ritter, J.K.; Wolf, C.; Zhang, S.; Poklis, A. Identification of metabolite biomarkers of the designer hallucinogen 25I-NBOMe in mouse hepatic microsomal preparations and human urine samples associated with clinical intoxication. J. Anal. Toxicol. 2015, 39, 607-616. [CrossRef] [PubMed]

30. Wohlfarth, A.; Roman, M.; Andersson, M.; Kugelberg, F.C.; Diao, X.; Carlier, J.; Eriksson, C.; Wu, X.; Konradsson, P.; Josefsson, M.; et al. 25C-NBOMe and 25I-NBOMe metabolite studies in human hepatocytes, in vivo mouse and human urine with high-resolution mass spectrometry. Drug Test. Anal. 2017, 9, 680-698. [CrossRef]

31. Caspar, A.T.; Helfer, A.G.; Michely, J.A.; Auwärter, V.; Brandt, S.D.; Meyer, M.R.; Maurer, H.H. Studies on the metabolism and toxicological detection of the new in psychoactive designer drug 2-(4-iodo-2,5-dimethoxyphenyl)-N-[(2-methoxyphenyl)methyl]ethanamine (25I-NBOMe) human and rat urine using GC-MS, LC-MS n, and LC-HR-MS/MS. Anal. Bioanal. Chem. 2015, 407, 6697-6719. [CrossRef] [PubMed]

32. Caspar, A.T.; Brandt, S.D.; Stoever, A.E.; Meyer, M.R.; Maurer, H.H. Metabolic fate and detectability of the new psychoactive substances 2-(4-bromo-2,5-dimethoxyphenyl)-N-[(2-methoxyphenyl)methyl]ethanamine (25B-NBOMe) and 2-(4-chloro-2,5dimethoxyphenyl)-N-[(2-methoxyphenyl)methyl]ethanamine (25C-NBOMe) in human and rat urine by GC-MS, LC-MS n, and LC-HR-MS/MS approaches. J. Pharm. Biomed. Anal. 2017, 134, 158-169. [CrossRef] [PubMed]

33. Nielsen, L.M.; Holm, B.; Leth-Petersen, S.; Kristensen, J.L.; Linnet, K. Characterization of the hepatic cytochrome P450 enzymes involved in the metabolism of 25I-NBOMe and 25I-NBOH. Drug Test Anal. 2016, 9, 671-679. [CrossRef] [PubMed]

34. Boumrah, Y.; Humbert, L.; Phanithavong, M. In vitro characterization of potential CYP- and UGT-derived metabolites of the psychoactive drug 25B-NBOMe using LC-high resolution MS. Drug Test Anal. 2016, 8, 248-256. [CrossRef] [PubMed]

35. Leth-Petersen, S.; Gabel-jensen, C.; Gillings, N.; Lehel, S.; Hansen, H.D.; Knudsen, G.M.; Kristensen, J.L. Metabolic fate of hallucinogenic NBOMes. Chem. Res. Toxicol. 2016, 26, 96-100. [CrossRef] [PubMed] 
36. Seo, H.; Kim, I.S.; Kim, Y.; Yoo, H.H.; Hong, J. Metabolic profile determination of 25N-NBOMe in human liver microsomes by liquid chromatography-quadrupole time-of-flight mass spectrometry. Int. J. Legal Med. 2019, 133, 833-841. [CrossRef] [PubMed]

37. Caspar, A.T.; Meyer, M.R.; Westphal, F.; Weber, A.A.; Maurer, H.H. Nano liquid chromatography-high-resolution mass spectrometry for the identification of metabolites of the two new psychoactive substances N-(ortho-methoxybenzyl)-3,4dimethoxyamphetamine and N-(ortho-methoxybenzyl)-4-methylmethamphetamine. Talanta 2018, 188, 111-123. [CrossRef] [PubMed]

38. Grafinger, K.E.; Stahl, K.; Wilke, A.; König, S.; Weinmann, W. In vitro phase I metabolism of three phenethylamines 25D-NBOMe, 25E-NBOMe and 25N-NBOMe using microsomal and microbial models. Drug Test Anal. 2018, 10, 1607-1626. [CrossRef]

39. Ketha, H.; Webb, M.; Clayton, L.; Li, S. Gas Chromatography Mass Spectrometry (GC-MS) for Identification of Designer Stimulants Including 2C Amines, NBOMe Compounds, and Cathinones in Urine. Curr. Protoc. Toxicol. 2017, 74, 4.43.1-4.43.10. [CrossRef] [PubMed]

40. Richter, L.H.J.; Maurer, H.H.; Meyer, M.R. New psychoactive substances. Studies on the metabolism of XLR-11, AB-PINACA, FUB-PB-22, 4-methoxy- $\alpha$-PVP, 25-I-NBOMe, and meclonazepam using human liver preparations in comparison to primary human hepatocytes, and human urine. Toxicol. Lett. 2017, 280, 142-150. [CrossRef]

41. Temporal, K.H.; Scott, K.S.; Mohr, A.L.A.; Logan, B.K. Metabolic profile determination of NBOMe compounds using human liver microsomes and comparison with findings in authentic human blood and urine. J. Anal. Toxicol. 2017, 41, 646-657. [CrossRef] [PubMed]

42. Caspar, A.A.T.; Meyer, M.R.; Maurer, H.H. Human cytochrome P450 kinetic studies on six N-2-methoxybenzyl (NBOMe)-derived new psychoactive substances using the substrate depletion approach. Toxicol. Lett. 2017, 285, 1-8. [CrossRef] [PubMed]

43. Leth-Petersen, S.; Bundgaard, C.; Hansen, M.; Carnerup, M.A.; Kehler, J.; Kristensen, J.L. Correlating the metabolic stability of psychedelic 5-HT 2A agonists with anecdotal reports of human oral bioavailability. Neurochem. Res. 2014, 39, 2018-2023. [CrossRef] [PubMed]

44. Campbell, J.L.; Collings, B.A.; Le Blanc, J.C.Y.; Hager, J.W. A novel MS3 experiment for quantifying ions with a linear ion trap. Can. J. Chem. 2018, 96, 653-663. [CrossRef]

45. Markus, B.; Kwon, C. In vitro metabolism of aromatic nitriles. J. Pharm. Sci. 1994, 83, 1729-1734. [CrossRef] [PubMed]

46. ThermoFisher. Available online: https://www.thermofisher.com/cz/en/home/references/protocols/drug-discovery/admetox-protocols / microsomes-protocol.html (accessed on 17 March 2021).

47. Chemistry Archive. Available online: https://erowid.org/archive/rhodium/chemistry/edda.html (accessed on 4 January 2021).

48. Butterick, J.R.; Unrau, A.M. Reduction of $\beta$-nitrostyrene with sodium bis-(2-methoxyethoxy)-aluminium dihydride. A convenient route to substituted phenylisopropylamines. J. Chem. Soc. Chem. Commun. 1974, 8, 307-308. [CrossRef]

49. Xu, Y.-Z.; Chen, C. Synthesis of deuterium labeled phenethylamine derivatives. J. Label Compd. Radiopharm. 2006, 49, 1187-2000. [CrossRef]

50. Cheng, A.C.; Castagnoli, N. Synthesis and physicochemical and neurotoxicity studies of 1-(4-substituted-2,5-dihydroxyphenyl)-2aminoethane analogues of 6-hydroxydopamine. J. Med. Chem. 1984, 27, 513-520. [CrossRef] [PubMed]

51. Hájková, K.; Jurásek, B.; Čejka, J.; Štefková, K.; Páleníček, T.; Sýkora, D.; Kuchař, M. Synthesis and identification of deschloroketamine metabolites in rats' urine and a quantification method for deschloroketamine and metabolites in rats' serum and brain tissue using liquid chromatography tandem mass spectrometry. Drug Test. Anal. 2020, 12, 343-360. [CrossRef] 